\title{
CARBON DIOXIDE, HYDROGRAPHIC, AND CHEMICAL DATA OBTAINED DURING THE R/V METEOR CRUISE 15/3 IN THE SOUTH ATLANTIC OCEAN (WOCE SECTION A9, FEBRUARY-MARCH 1991)
}

\author{
Contributed by \\ Kenneth M. Johnson;, Douglas W. R. Wallace', Richard J. Wilke*, and \\ Catherine Goyet"* \\ Brookhaven National Laboratory \\ Upton, New York \\ "Woods Hole Oceanographic Institution \\ Woods Hole, Massachusetts \\ Prepared by Alexander Kozyr \\ Carbon Dioxide Information Analysis Center \\ Oak Ridge National Laboratory \\ Oak Ridge, Tennessee \\ Environmental Sciences Division \\ Publication No. 4416 \\ Date Published: June 1995 \\ Prepared for the \\ Global Change Research Program \\ Environmental Sciences Division \\ Office of Health and Environmental Research \\ U.S. Department of Energy \\ Budget Activity Number KP 0502000 \\ Prepared by the \\ Carbon Dioxide Information Analysis Center \\ OAK RIGE NATIONAL LABORATORY \\ Oak Ridge, Tennessee 37831-6335 \\ managed by \\ MARTIN MARIETTA ENERGY SYSTEMS, INC. \\ for the \\ U.S. DEPARTMENT OF ENERGY \\ under contract DE-AC05-840R21400
}

This research was performed under the auspices of the United States Department of Energy under

Contract No. DE-AC02-76CH00016. 



\section{CONTENTS}

$\underline{\text { Page }}$

LIST OF FIGURES $\ldots \ldots \ldots \ldots \ldots \ldots \ldots \ldots \ldots \ldots \ldots \ldots \ldots \ldots \ldots \ldots, v$

LIST OF TABLES $\ldots \ldots \ldots \ldots \ldots \ldots \ldots \ldots \ldots \ldots \ldots \ldots \ldots \ldots \ldots$ vii

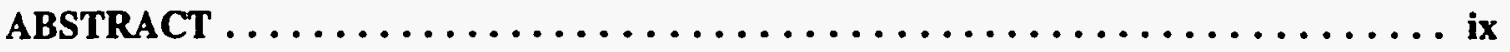

PART 1: OVERVIEW $\ldots \ldots \ldots \ldots \ldots \ldots \ldots \ldots \ldots \ldots \ldots \ldots \ldots \ldots \ldots$. 1

1. BACKGROUND INFORMATION $\ldots \ldots \ldots \ldots \ldots \ldots \ldots \ldots \ldots \ldots \ldots$

2. DESCRIPTION OF THE EXPEDITION $\ldots \ldots \ldots \ldots \ldots \ldots \ldots \ldots \ldots \ldots$

2.1 R/V Meteor, Technical Details and History $\ldots \ldots \ldots \ldots \ldots \ldots \ldots \ldots, 5$

$2.2 \mathrm{R} / \mathrm{V}$ Meteor Cruise $15 / 3$ Information $\ldots \ldots \ldots \ldots \ldots \ldots \ldots \ldots \ldots$

2.3 Brief Cruise Summary $\ldots \ldots \ldots \ldots \ldots \ldots \ldots \ldots \ldots \ldots \ldots \ldots$

3. DESCRIPTION OF VARIABLES AND METHODS $\ldots \ldots \ldots \ldots \ldots \ldots \ldots 8$

4. DATA CHECKS AND PROCESSING PERFORMED BY CDIAC $\ldots \ldots \ldots \ldots 18$

5. HOW TO OBTAIN THE DATA AND DOCUMENTATION $\ldots \ldots \ldots \ldots 22$

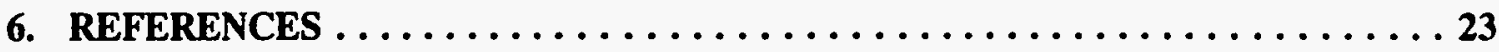

PART 2: CONTENT AND FORMAT OF DATA FILES $\ldots \ldots \ldots \ldots \ldots \ldots \ldots 25$

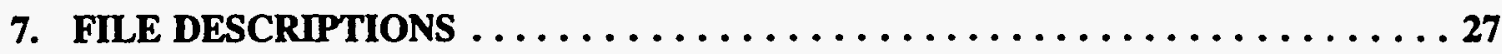

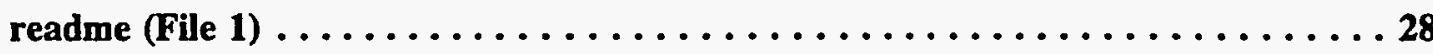

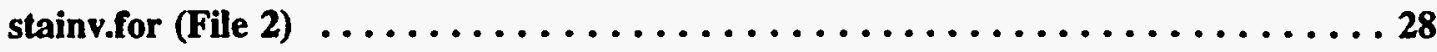

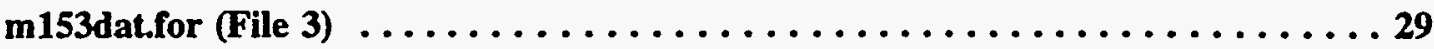

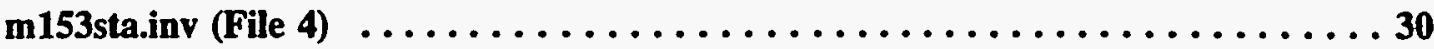

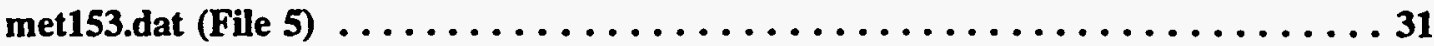


8. VERIFICATION OF DATA TRANSPORT 


\section{DISCLAIMER}

Portions of this document may be illegible in electronic image products. Images are produced from the best available original document. 


\section{LIST OF FIGURES}

1 Station locations during RV Meteor Cruise 15/3 (WOCE Section A9) . . . . . . . 4

2 Sampling depths at all hydrographic stations occupied during R/V Meteor

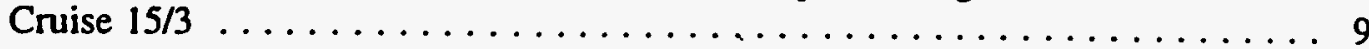

3 Distribution of the total $\mathrm{CO}_{2}$ in seawater along WOCE Section $\mathrm{A9} \ldots \ldots \ldots 12$

4 Comparison of discrete partial pressure of carbon dioxide and total carbon dioxide profiles at Station 199 of R/V Meteor Cruise 15/3 (March 1991) to those from South Atlantic Ventilation Experiment Station 144 (February 1988) . . . . . . . 16

5 Nested profiles: total carbon $(\mu \mathrm{mol} / \mathrm{kg})$ vs pressure (dbar) for Stations $132-190 \ldots 19$

6 Nested profiles: total carbon $(\mu \mathrm{mol} / \mathrm{kg}$ ) vs pressure (dbar) for Stations $193-232 \ldots 20$

7 Property-property plots for all stations occupied during R/V Meteor Cruise 15/3 . . 21

\section{DISCLAIMER}

This report was prepared as an account of work sponsored by an agency of the United States Government. Neither the United States Government nor any agency thereof, nor any of their employees, makes any warranty, express or implied, or assumes any legal liability or responsibility for the accuracy, completeness, or usefulness of any information, apparatus, product, or process disclosed, or represents that its use would not infringe privately owned rights. Reference herein to any specific commercial product, process, or service by trade name, trademark, manufacturer, or otherwise does not necessarily constitute or imply its endorsement, recommendation, or favoring by the United States Government or any agency thereof. The views and opinions of authors expressed herein do not necessarily state or reflect those of the United States Government or any agency thereof. 


\section{LIST OF TABLES}

Table

1 Results of the certified reference material (batch 2) shipboard analyses during R/V Meteor Cruise 15/3 February-March $1991 \ldots \ldots \ldots \ldots \ldots$

2 Comparison of shipboard analyses of total carbon dioxide by coulometry (BNL) during R/V Meteor Cruise 15/3 with the shore-based reference analyses by manometry on duplicate samples by C. D. Keeling, Scripps Institution of

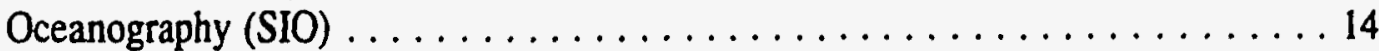

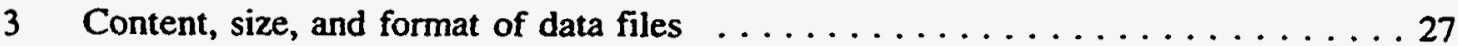

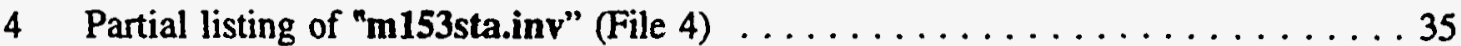

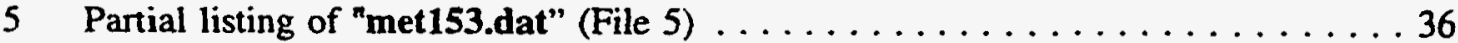

A.1 Station inventory information for the 111 sites occupied during

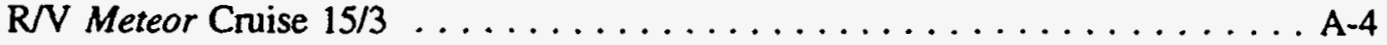




\begin{abstract}
Johnson, K. M., D. W. R. Wallace, R. J. Wilke, and C. Goyet. 1995. Carbon Dioxide, Hydrographic, and Chemical Data Obtained During the R/V Meteor Cruise 15/3 in the South Atlantic Ocean (WOCE Section A9, February-March 1991). ORNLCDIAC-82, NDP-051. Carbon Dioxide Information Analysis Center, Oak Ridge National Laboratory, Oak Ridge, Tennessee. 54 pp.
\end{abstract}

This data documentation discusses the procedures and methods used to obtain data on total carbon dioxide $\left(\mathrm{TCO}_{2}\right)$, total alkalinity (TALK), and discrete partial pressure of $\mathrm{CO}_{2}\left(\mathrm{pCO}_{2}\right)$ during the Research Vessel (R/V) Meteor Expedition 15/3 in the South Atlantic Ocean (Section A9). Conducted as part of the World Ocean Circulation Experiment (WOCE), the cruise began in Vitoria, Brazil, on February 10, 1991, and ended in Pointe-Noire, Congo, on March 23, 1991. WOCE zonal Section A9 began at $\sim 38^{\circ} \mathrm{W}$ and continued along the $19^{\circ} \mathrm{S}$ parallel until $\sim 8^{\circ} \mathrm{E}$. Samples were collected for $\mathrm{TCO}_{2}$ from 28 stations along the 19th parallel and at 3 diversions north and south of the 19th parallel. The latter stations were occupied to track bottom water movements. Measurements made along WOCE Section A9 included pressure, temperature, salinity, and oxygen measured by conductivity, temperature and depth sensor (CTD); bottle salinity, oxygen, phosphate, nitrate, nitrite, silicate, CFC-113, CCl $, \mathrm{CFC}-12, \mathrm{CFC}-11, \mathrm{TCO}_{2}$, TALK, and $\mathrm{pCO}_{2}$ measured at $20^{\circ} \mathrm{C}$. Replicate samples from ten Niskin bottles at four stations were also collected for later shore-based reference analyses of $\mathrm{TCO}_{2}$ and TALK by vacuum extraction and manometry in the laboratory of Dr. Charles Keeling, Scripps Institution of Oceanography (SIO).

The $\mathrm{TCO}_{2}$ was measured using an automated sample processor (SOMMA) for extracting $\mathrm{CO}_{2}$ from seawater samples coupled to a Coulometer for detection of the extracted gas. The precision and accuracy of the system was $\pm 1.0 \mu \mathrm{mol} / \mathrm{kg}$. R/V Meteor Cruise $15 / 3$ was an initial test of an experimental system for measuring $\mathrm{pCO}_{2}$ on discrete water samples: a batch equilibration technique was used followed by headspace gas chromatography with flame ionization detection. While the quality of some $\mathrm{pCO}_{2}$ data is poor compared with that collected more recently (i.e., precision and accuracy $-2-3 \%$ ), all data have been included for completeness. Samples collected for TALK were measured using standard potentiometric techniques; precision was $\pm 2.6 \mu \mathrm{mol} / \mathrm{kg}$.

The R/V Meteor Cruise 15/3 data set is available free-of-charge as a numeric data package (NDP) from CDIAC. The NDP consists of five data files and this printed documentation, which describes the contents and format of all data files as well as the procedures and methods used to obtain the data.

Keywords: carbon dioxide; World Ocean Circulation Experiment; South Atlantic Ocean; hydrographic measurements; carbon cycle 
PART 1:

OVERVIEW 


\section{BACKGROUND INFORMATION}

The increase in atmospheric carbon dioxide $\left(\mathrm{CO}_{2}\right)$ concentrations (as well as in other radiatively active trace gases) because of human activity has produced serious concern regarding the heat balance of the global atmosphere (Moore and Braswell 1994). The increasing

may | concentrations of these gases int intensify the earth's natural greenhouse effect, shifter the global climate system in ways that are not well understood. The oceans play a major role in global carbon cycle processes. Carbon in the oceans is unevenly distributed because of complex circulation patterns and biogeochemical cycles, neither of which je completely / are

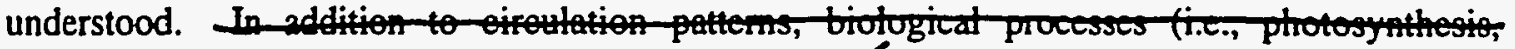
delte 1

To better understand the ocean's role in climate and climatic changes, several large experiments have been conducted in the past, and others are currently under way. The World Ocean Circulation Experiment (WOCE) is a major component of the World Climate Research Program. Although total carbon dioxide $\left(\mathrm{TCO}_{2}\right)$ is not an official WOCE measurement, a coordinated effort, supported in the United States by the U.S. Department of Energy (DOE), is being made on WOCE cruises (through 1998) to measure the global, spatial, and temporal distributions of $\mathrm{TCO}_{2}$ and other carbon-related parameters. The $\mathrm{CO}_{2}$ survey goals include estimation of the meridional transport of inorganic carbon in a manner analogous to the oceanic heat transport (Bryden and Hall 1980; Brewer et al. 1989; Roemmich and Wunsch 1985), evaluation of the exchange of $\mathrm{CO}_{2}$ between the atmosphere and the ocean, and preparation of a database suitable for carbon-cycle modeling and the subsequent assessment of anthropogenic $\mathrm{CO}_{2}$ increase in the oceans. The $\mathrm{CO}_{2}$ survey is taking advantage of the sampling opportunities provided by the WOCE cruises during this period. The final data set is expected to cover $-23,000$ stations.

This document describes the first effort by chemical oceanographers from Brookhaven National Laboratory (BNL) to make high-quality $\mathrm{CO}_{2}$ measurements during a 42-day expedition in the South Atlantic Ocean aboard the Research Vessel (R/V) Meteor in the austral summer of 1991. Designated Expedition 15/3, Khe cruise departed Vitona, Brazil, on February 10, 1991, and arrived in Pointe-Noire, Congo, on March 23, 1991. The WOCE zonal Section is A9 (Fig. 1).

The $\mathrm{CO}_{2}$ investigation during R/V Meteor Cruise $15 / 3$ was supported by DOE grant DEACO2-76CH00016. 


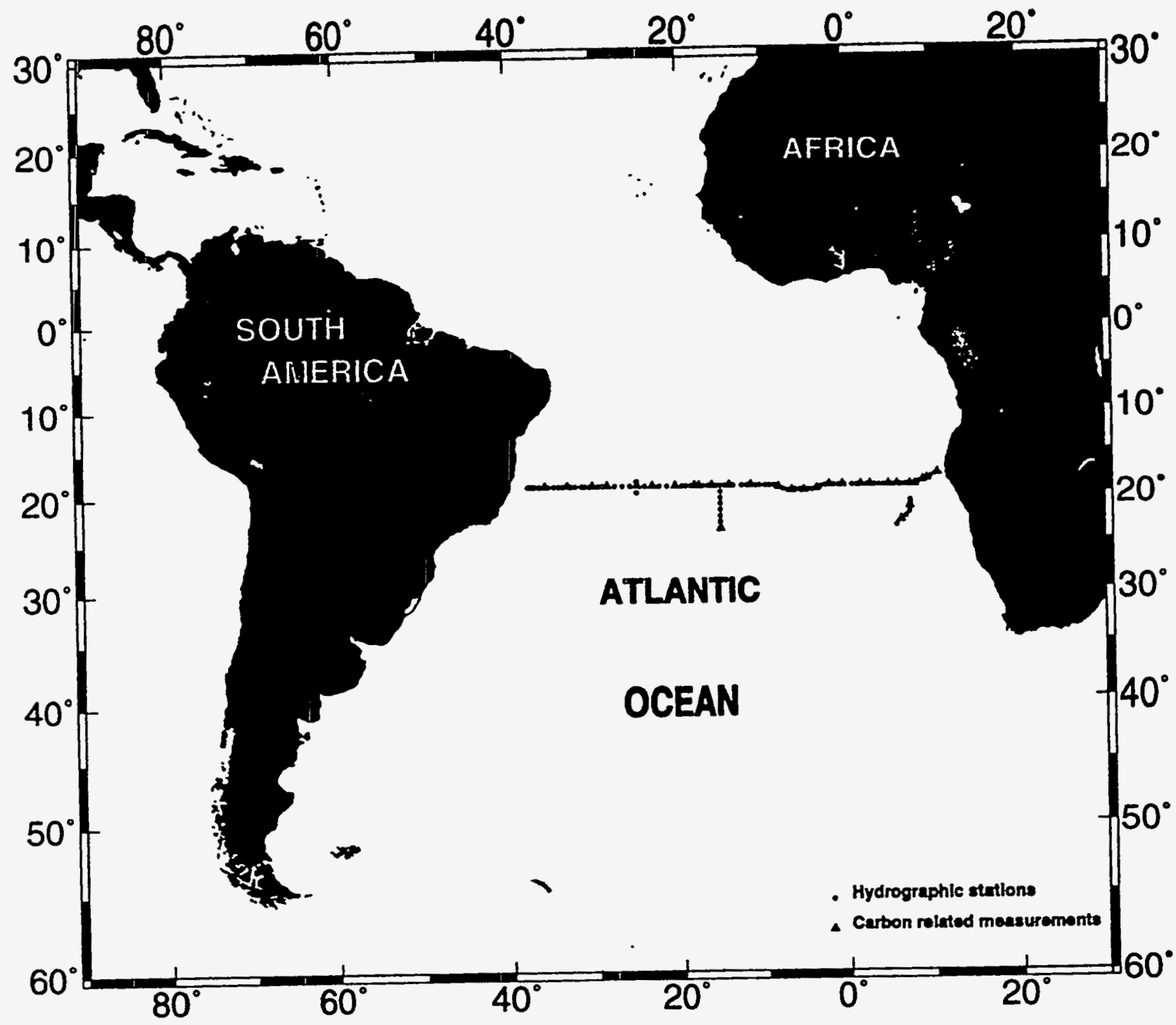

Figure 1. Station locations during R/V Meteor Cruise 15/3 (WOCE Section A9). 


\section{DESCRIPTION OF THE EXPEDITION}

\subsection{R/V Meteor, Technical Details and History}

The R/N Meteor is owned by the Federal Republic of Germany through the Ministry of Research and Technology (BMFT), which financed its construction. It is operated by the German Research Foundation (DFG), which provides about $70 \%$ of its operating funds (the BMFT supplies the remainder). DFG also plans the scientific cruises and appoints the chief scientists. The Operations Control Office of the University of Hamburg is responsible for management, logistics, execution and supervision of ship operations. These functions are exercised by direct cooperation with expedition coordinators and the managing owners, the Reedereigemeinschaft Forschungsschiffahrt $\mathrm{GmbH}$, located in Bremen, Germany. The latter is responsible for hiring, provisioning, and coordinating ship maintenance. Used for ocean research, primarily in the Atlantic and Indian Oceans, the R/V Meteor routinely carries scientists from many different countries. The Meteor was completed in 1986 in Travemunde, Germany. The basic features of the vessel follow:

Port of registration
Call sign
Classification
Operator
Built
Basic dimensions
$\quad$ gross registered tonnage
$\quad$ net registered tonnage
$\quad$ displacement
$\quad$ length overall
$\quad$ beam
$\quad$ draught max.
$\quad$ service speed
$\quad$ depth main deck
Personnel
Main engine
Propulsion
Fuel consumption
Maximum cruise duration
Nautical equipment

Science quarters

\author{
Hamburg \\ DBBH \\ GL+100A4E2+MC Auto \\ University of Hamburg, Institute for Ocean Research \\ 1985-1986 at Schlichting Werft, Travemunde
}

$97.50 \mathrm{~m}$

$16.50 \mathrm{~m}$

$5.60 \mathrm{~m}$

$12 \mathrm{kn}$

$7.70 \mathrm{~m}$

Crew: 32 ; Scientists: 30

$4 \times$ Mak6M $322=4 \times 1000 \mathrm{~kW}$ at $750 \mathrm{rpm}$

Diesel-electrical, tandem-motor $=2 \times 1150 \mathrm{~kW}$

Approximately $12.0 \mathrm{t}$ IFO-80 per day at service speed

60 days

Integrated navigation system with data transfer to position computer, echosounder synchronization and supervision, and data-processing facility

20 laboratories on the main deck with $-400 \mathrm{~m}^{2}$ of working space for multidisciplinary research

Meteor (I) was constructed in 1925, the first research and survey vessel of that name. Owned by the German navy, it was based in Wilhelmshaven. One of its first expeditions was the German Atlantic Ocean Expedition of 1925-1927, which was organized by the Institute of Marine Research in Berlin. Thereafter, the vessel was used for German physical, chemical, and microbiological marine investigations and for navy surveying and fisheries protection duties. 
Meteor (II) was planned after the 1950s; it was operated by the Deutsche Forschungsgemeinschaft (German Science Community) in Bad Godesberg and the Deutsches Hydrographisches Institut (German Hydrographic Institute) in Hamburg. Commissioned in 1964, Meteor (II) participated in the International Indian Ocean Expedition.

Multipurpose Meteor (III), used on the cruise described in this documentation, was completed in 1986, replacing Meteor (II). Based in Hamburg, it is used for German ocean research worldwide and for cooperative efforts with other nations in this field. The vessel serves scientists of all marine disciplines in all of the world's oceans.

\subsection{R/V Meteor Cruise 15/3 Information}

$\mathrm{R} / \mathrm{V}$ Meteor $15 / 3$ cruise information follows:

\begin{tabular}{|c|c|}
\hline Ship name & Meteor \\
\hline Cruise/leg & $15 / 3$ \\
\hline Location & Vitoria, Brazil, to Pointe-Niore, Congo \\
\hline Dates & February 10-March 23, 1991 \\
\hline Funding & $\begin{array}{l}\text { German Science Community, } \\
\text { Federal Ministry of Research and Technology, Bonn, Germany, and } \\
\text { U.S. DOE }\end{array}$ \\
\hline Chief Scientist & $\begin{array}{l}\text { Gerold Siedler } \\
\text { University Bfemon }\end{array}$ \\
\hline Master & H. Bruns \\
\hline
\end{tabular}

Parameters measured

CTD, salinity

Nutrients

Oxygen

CFC's alf winity

Exts

Tritium and ${ }^{3} \mathrm{He}$

$\mathrm{TCO}_{2}$, and $\mathrm{pCO}_{2}$

$\mathrm{CCl}_{4}$ and $\mathrm{CFC's}$

$\mathrm{XBT}, \mathrm{ADCP}$ and XCP

Dimethyl sulfide

Aerosols and particles

Participating Institutions

BNL

IFMK

IFMW

MPI

UBT

OSU

SIO

\section{Institution}

IFMK

SIO, OSU

IFMW

UBT

UBT

BNL, WHOI

BNL

IFMK

MPI

MPI
Principal investigators

R. Onken, T. Müller

J. Swift, D. Bos, J. Jennings

D. Nehring

W. Roether, P. Beining

W. Roether, P. Beining

K. M. Johnson, D. Wallace,, bo YET

D. Wallace, R. J. Wilke

R. Onken, T. Müller

A. Andrae, T. Andrae

A. Andrae, S. de Mora

Brookhaven National Laboratory

Institut fuer Meereskunde Kiel

Institut fuer Meereskunde Wamemünde

Max Planck Institut Mainz

University of Bremen, Tracer Oceanography Laboratory

Oregon State University

Scripps Institution of Oceanography 


\subsection{Brief Cruise Summary}

Gerold Siedler relieved Walter Zenk as chief scientist upon completion of the RV Meteor Cruise 15/2 on February 8, 1991, in Vitoria, Brazil; the remaining participants were on board by February 9. Equipment setup began on February 8. The RN Meteor departed Vitoria at 9 am on February 10, 1991, and steamed to its initial position of $19^{\circ} \mathrm{S}, 38^{\circ} \mathrm{W}$. On February 11 the ship began a short zonal section across the Brazil Current characterized by closely spaced expendable bathythermograph (XBT) launches and acoustic Doppler current profiling (ADCP). A test station was made to check CTD operation and possible contamination of the 10-liter Niskin bottles for CFC's. From these results and the earlier profiles, a decision was made to run westward to the $500-\mathrm{m}$ isobath where the Section A9 began with a set of eight closely spaced expendable current profiler (XCP) and CTD profiles including the standard measurements (nutrients, $\mathrm{O}_{2}, \mathrm{CO}_{2}$, tracers) as the ship steamed once again eastward across the Brazil Current and into the open ocean along $19^{\circ} \mathrm{S}$. Neither tracer nor $\mathrm{CO}_{2}$ samples could be taken on all CTD stations because of the time required for analysis. The density of the $\mathrm{CO}_{2}$ sampling was gradually increased during the first week until at least one $\mathrm{CO}_{2}$ station was completed each day. Initial delays were aggravated by high ( +3 to $10 \mu \mathrm{mol} / \mathrm{kg}$ ) $\mathrm{TCO}_{2}$ results for the certified reference material (CRM) analyses with respect to the certified value. It was initially assumed that the problem lay with the SOMMA-Coulometer system or its software, and time was lost troubleshooting. After analyzing a limited number of samples from an earlier CRM batch (see Table 1 on page 13) over several days, it was found that the measurement system was operating properly and that the new CRM batch supplied especially for the cruise was at fault. This was confirmed by subsequent testing. Figure 1 (pg. 4) shows the station positions where $\mathrm{CO}_{2}$ parameters were measured.

To compare these data with data from the earlier U.S. South Atlantic Ventilation Experiment (SAVE) Program, the normal station routine (i.e., every $30 \mathrm{~nm}$ ) was interrupted at $25^{\circ} \mathrm{W}$ between February 19 and 20 for an additional freestations north and south of $19^{\circ} \mathrm{S}$. To identify deep water movements on the western edge of the Mid-Atlantic Ridge, between February 25 and 27 a short meridional section comprising seven stations was carried out from $19^{\circ} 00^{\prime} \mathrm{S}$ to $23^{\circ} 40^{\prime} \mathrm{S}$. Between March 3 and 6 the ship veered slightly southward to avoid the 200-mile commerce zone belonging to the island of St. Helena (United Kingdom). Between March 12 and 15 a diversion was made at $7^{\circ} \mathrm{E}$ to the Walvis Ridge, and eight CTD stations were taken along a track parallel to the ridge to study deep water movements in this region. The shiprontinuedzonal section / the along $19^{\circ} \mathrm{S}$ until $\sim 8^{\circ} \mathrm{E}$ where a course change to east-northeast was made. To adequately sample the eastern boundary current up to the continental shelf, the distance between stations at this point was reduced from 30 to $10 \mathrm{~nm}$. On March 19, 1991 WOCE Zonal Section A9 was completed. The ship steamed to Pointe-Noire, Congo, arriving on March 23, 1991. Weather and sea conditions were excellent throughout the cruise. 


\section{DESCRIPTION OF VARIABLES AND METHODS}

The data file met153.dat (see description in Part 2) in this numeric data package (NDP) contains the following variables: station numbers; cast numbers; sample numbers; bottle numbers; CTD pressures, temperatures, salinities, and oxygen; potential temperatures; bottle salinities; concentrations of dissolved oxygen, silicate, nitrate, nitrite, and phosphate; $\mathrm{TCO}_{2}$ and TALK concentrations; partial pressure of $\mathrm{CO}_{2}\left(\mathrm{pCO}_{2}\right)$ measured at $20^{\circ} \mathrm{C} ; \mathrm{CEE}-113 ; \mathrm{CCl} 4 \mathrm{CFC}-12 ; \mathrm{CFC}$ 11 ; and quality flags. The station inventory file m153sta.inv ( $\mathrm{Par} / 2$ ) contains expocodes, section numbers, station numbers, cast numbers, sampling dates (i.e., day, month, year), sampling times, latitude, longitude, and bottom depth for each station.

Water samples were collected by a General Oceanics rosette equipped with 2410 - bottles mounted on a Neil Brown Mark III instrument (IFMK numbers NB3 and NB2) fwith $_{\text {an }} \mathrm{O}_{2}$ sensor and bottom alarm. Using IFMK software by L. Bellach, pressure, temperature, conductivity, oxygen, and sensor temperature data were recorded on a PC at the full sampling rate of $32 \mathrm{~Hz}$ in binary form and at a reduced sampling rate of $3 \mathrm{~Hz}$ on a Micro Vax computer. Reversing thermometef were included on bottles 1 and 23 (deepest and mixed-layer sample); each rack consisted of yeet thermometers. The CTD pressure, temperature, oxygen, and conductivity data were processed and corrected according to laboratory calibrations in 1990 and 1991, and in situ measurements, according to procedures written by Ruhsam (1994) and Siedler and Zenk (1992). Pressure values are expected to be accurate to $\pm 3 \mathrm{dbar}$; temperature to $\pm 0.002^{\circ} \mathrm{C}$. Salinity for selected Niskin bottles (about one in every tret) was also determined on a Guildline Autosal model $8400 \mathrm{~A}$, that was standardized weekly with International Association for the Physical Sciences of the Ocean (LAPSO) water (batch P112). These data were also used to process the CTD data, and the final salinity data are expected to be accurate to $\pm 0.002 /$ Practical $^{\text {a }}$ Salinity Scale (PSS). Oxygen was determined on each Niskin bottle by the Winkler method as modified by Grasshoff et al. (1983). Duplicates were taken periodically to estimate the accuracy and precision of the entire sampling procedure, which was determined to be $\pm 1 \mu \mathrm{mol} / \mathrm{kg}$. The concentrations of nitrate, nitrite, phosphate, and silicate dissolved in seawater were determined on a continuous flow analyzer: the Alpkem Corporation RFA 300, which was used in conjunction with a data acquisition system supplied by Oregon State University. The analyses were completed within $24 \mathrm{~h}$ after sampling.

The $\mathrm{TCO}_{2}$ was determined using an automated coulometric system (SOMMA) (Johnson et al. 1985; Johnson et al. 1987; Johnson and Wallace 1992). Some 753 individual samples, along with 145 duplicates from 29 stations (Fig. 2), were collected in $300-\mathrm{mL}$ precombusted $\left(450^{\circ} \mathrm{C}\right.$ for $24 \mathrm{~h}$ ) bottles and immediately poisoned with $\mathrm{HgCl}_{2}$ according to the DOE Handbook of Methods (DOE 1994). Before analysis, samples were kept in darkness until thermally equilibrated to the pipette temperature. CRM supplied by Andrew G. Dickson, of SIO (DOE 1994), were also analyzed. CRMs are filtered sterile salt solutions or seawater spiked with $\mathrm{Na}_{2} \mathrm{CO}_{3}$, analyzed for $\mathrm{TCO}_{2}$ concentration by vacuum-extraction/manometry in the laboratory of Charles D. Keeling at SIO.

For analysis, seawater introduced from an automated "To Deliver" pipette into a stripping chamber was acidified, and the resultant $\mathrm{CO}_{2}$, after drying, was coulometrically titrated on a model 5011 UIC coulometer. In the coulometer cell the hydroxyethylcarbamic acid, formed from the reaction of $\mathrm{CO}_{2}$ and ethanolamine, was titrated coulometrically (electrolytic generation of $\mathrm{OH}^{-}$) 


\section{WOCE Section A9}

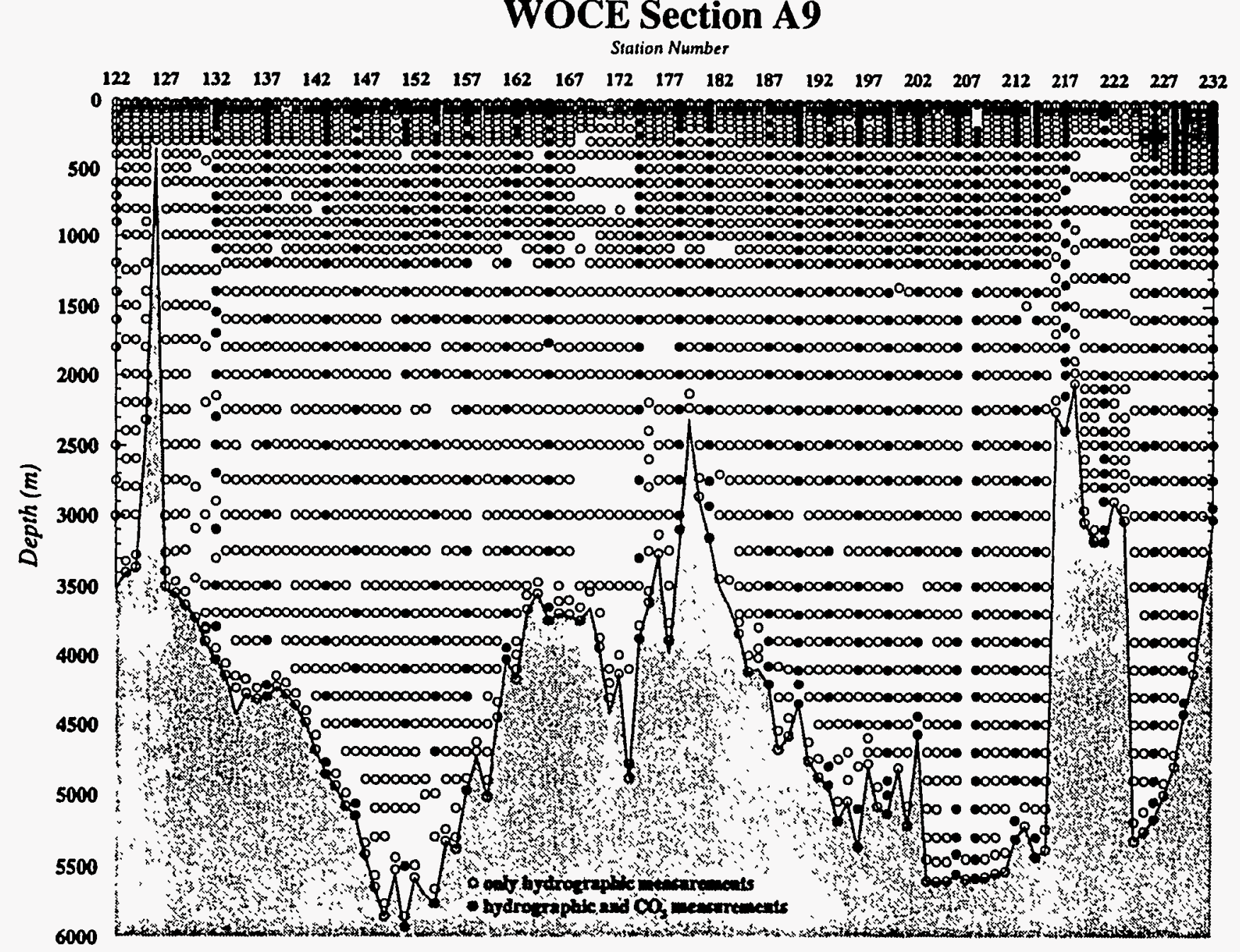

Figure 2. Sampling depths at all hydrographic stations occupied during R/V Meteor Cruise 15/3. 


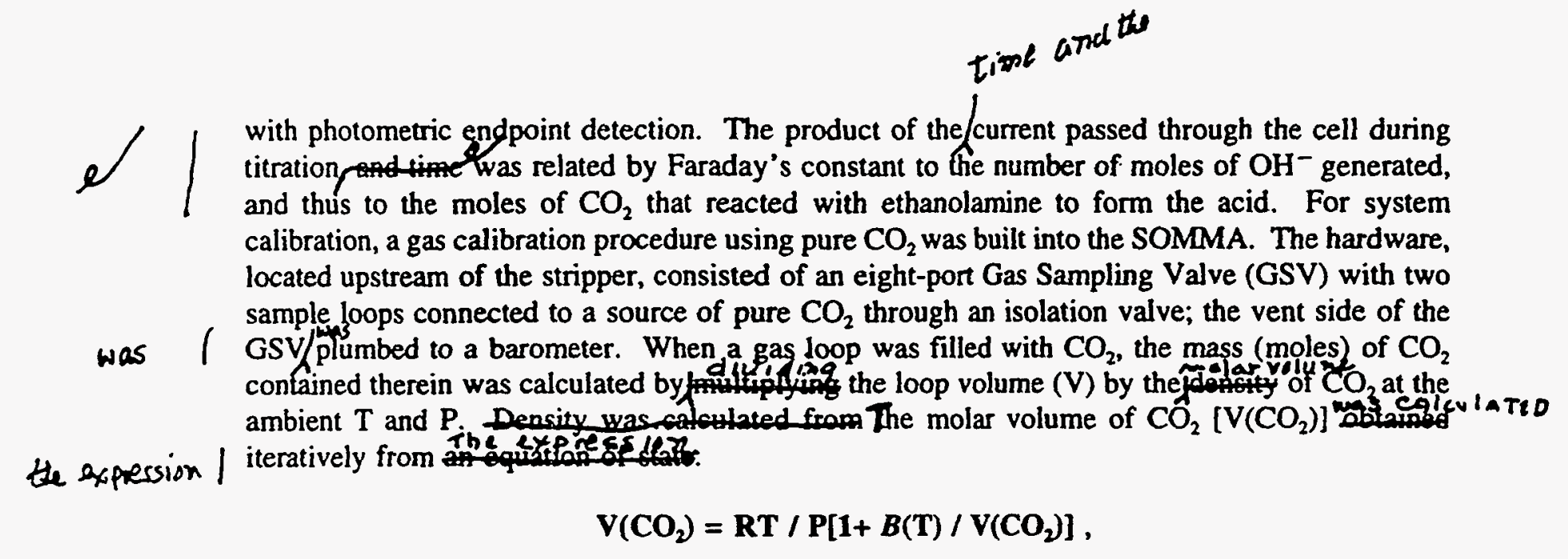

were $P$ is the instantaneous barometric pressure, $T$ is the loop temperature, and $B(T)$ is the first virial coefficient for pure $\mathrm{CO}_{2}$. The ratio of the calculated mass to that determined coulometrically was the gas calibration factor (CALFAC) used to correct the subsequent titrations for small departures from $100 \%$ theoreticall The volume of the loops was determined gravimetrically with deionized water by the method of Wilke et al. (1993).

The "to deliver" volume (TDV) of the SOMMA sample pipette was determined gravimetrically with milli-Q deionized water degassed with helium. The thermostatted sample pipette was filled with water at the same temperature and then discharged into preweighed $50-\mathrm{mL}$ serum bottles that were reweighed on a model R300S (Sartorius, Göttingen, Germany) balance. The apparent weight $(\mathrm{g})$ of water collected $\left(\mathrm{W}_{\text {avi }}\right)$ was corrected to the mass in vacuo $\left(\mathrm{M}_{\mathrm{vac}}\right)$ from

$$
\mathrm{M}_{\mathrm{vac}}=\mathrm{W}_{\mathrm{arr}}+\mathrm{W}_{\mathrm{arr}}(0.0012 / d-0.0012 / 8.0) \text {, }
$$

where 0.0012 is the sea level density of air at $1 \mathrm{~atm}, d$ is the density of the calibration fluid at the pipette temperature and sample salinity, and 8.0 is the density of the stainless steel weights. The TDV was

$$
\mathrm{TDV}=\mathrm{M}_{\mathrm{vac}} / d
$$

The precruise calibrated TDV of the pipette was $28.7113 \pm 0.003 \mathrm{~mL}(n=8)$ at $20^{\circ} \mathrm{C}$. During the cruise, 52 preweighed serum bottles were filled from the pipette. They were sealed and returned to the laboratory for reweighing. The mean volume from these bottles was $28.7172 \pm$ 0.0096 at $20^{\circ} \mathrm{C}$. The mean difference between the precruise and postcruise results was $0.0059 \mathrm{~mL}$ which is less than the standard deviation of the 52 postcruise weighings; accordingly, $\mathrm{TCO}_{2}$ calculated using the precruise volume of $28.7113 \mathrm{~mL}$.

An LBM compatible computer with two RS232 serial, a 24-line digital input/output, and analog-to-digital ports was used to control the coulometer, barometer, solid state control relays, and temperature sensors, respectively. The temperature sensors (model LM34CH, National Semiconductor, Santa Clara, California) with a voltage output of $10 \mathrm{mV} /{ }^{\circ} \mathrm{F}$ were calibrated against thermistors certified to $0.01^{\circ} \mathrm{C}$ (PN CSP60BT103M, Thermometrics, Edison, New Jersey) with a certified mercury thermometer as a secondary standard. These sensors monitored the pipette, gas sample loop, and the coulometer cell temperatures. The barometer, model 216B-101 Digiquartz Transducer (Paroscientific, Inc., Redmond, Washington) was factory-calibrated for psia | pressures between 11.5 and 16.0psi. The SOMMA software was written in GWBASIC Version Psia 
3.20 (Microsoft Corp., Redmond, Washington), and the instrument was driven from an options menu appearing on the personal computer monitor.

Titrations were done with the coulometer in the counts mode: the total charge passed during a titration was displayed as the total number of counts accumulated by the coulometer's voltageto-frequency converter (VFC). From the factory calibration of the VFC [frequency $=10^{5}$ pulses

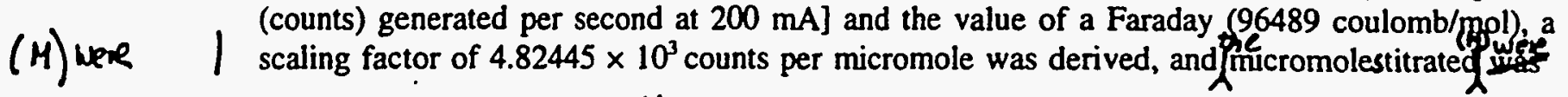
$M \mid \quad$ M counts/4824.45 - (blank $\left.\times \mathrm{T}_{\mathrm{T}}\right)$,

where $T_{T}$ was the length of the titration in minutes and blank was the system blank in micromoles per minute. The total carbon dioxide concentration in micromole per killom was calculat as follows: umol/ $\mathrm{kg}$
$M /$
$M$
$\mathrm{TCO}_{2}=[$ CALFAC $\left.)\left(1000 / \mathrm{TDV}_{\mathrm{C}} \times p\right)\right] \times 1.00017$,

where CALFAC is the gas calibration factor, $\operatorname{TDV}_{\mathrm{c}}$ is the "to deliver" volume of the pipette in milliliters corrected for the thermal expansion of glass, $p$ is the density of sea water in kilograms per liter from the equation of state (Millero and Poisson 1981), and 1.00017 corrects for the addition' of 1 dilution of the sample by $\left(100 \mu \mathrm{L}\right.$ of $\mathrm{HgCl}_{2}$ solution Precision for â set of analyzed samples was expressed as the square root of the pooled variance $\left(\mathrm{S}_{\mathrm{p}}{ }^{2}\right)$ calculated according to Youden (1951):

\section{|the}

$$
\text { expressed as the square rool of the pooled variance }\left(S_{p}{ }^{2}\right) \text { calculated according Youden (1951). }
$$

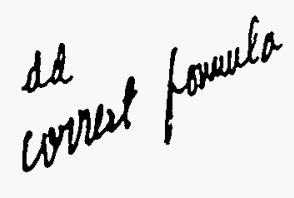

$$
\sqrt{\frac{\sum_{j=1}^{k}\left(\sum_{i=1}^{n_{j}}\left[x_{i j}-\bar{x}_{j}\right\}^{2}-\left\{\sum_{i=1}^{n_{j}}\left[x_{i j}-\bar{x}_{j}\right]\right\}^{2} / n_{i}\right)}{\sum_{j=1}^{k} n_{j}-k}}
$$

Where $k$ is the number of samples analyzed, and $\sum_{j}^{k} n_{j}-k$ is the degrees of freedom i.e., the total number of
replicates analyzed minus the number of samples. $j=1$

unstable and uncertifiable, data from this batch cannot be used to evaluate the performance of the $\mathrm{TCO}_{2}$ measurement system. Figure 3 summarizes the analytical results as a contour section plot of the $\mathrm{TCO}_{2}$ data from the $\mathrm{A} 9$ transect along $19^{\circ} \mathrm{S}$.

Replicate samples from ten Niskin bottles at four stations were also collected for later shorebased reference analyses of $\mathrm{TCO}_{2}$ by vacuum extraction and manometry by Charles $\mathrm{D}$. Keeling, SIO. The results (Table 2), extracted from Guenther et al. (1994), were obtained very early in the program for comparing shipboard analyses by coulometry with shore-based analyses of duplicate 


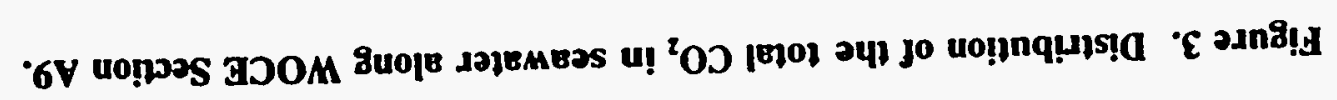

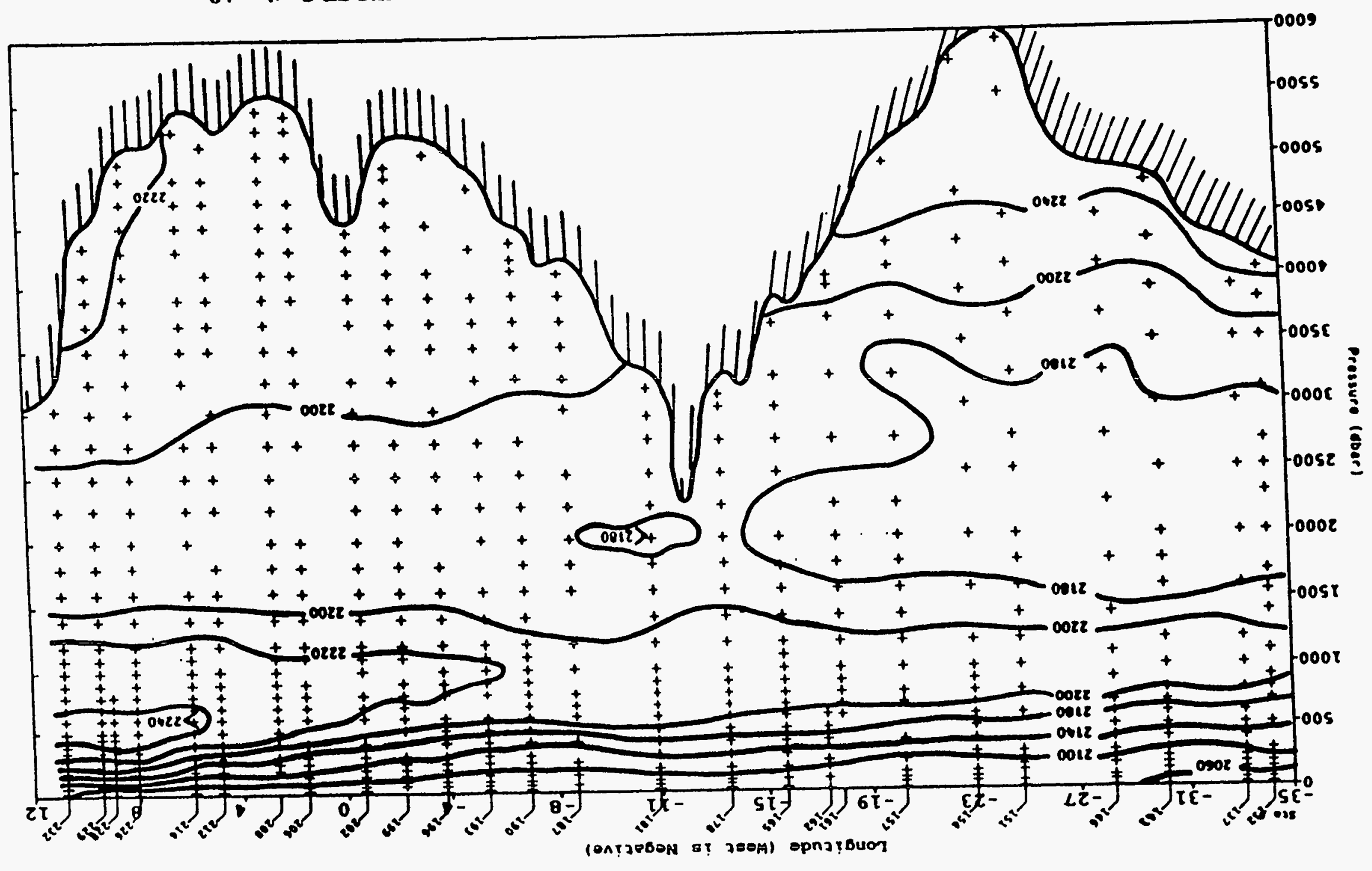

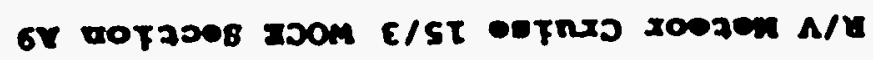


samples, and many mistakes and false starts were For example, experimentation with the most suitable sample bottle for this purpose was not yet completed, nor had storage precautions

Table 1. Results of the certified reference material (batch 2) shipboard analyses during R/V Meteor Cruise 15/3 February-March 1991.

The CRM had a certified $\mathrm{TCO}_{2}$ of $1978.8 \mu \mathrm{mol} / \mathrm{kg}$ and salinity of 33.361 PSS.

\begin{tabular}{|c|c|c|c|c|}
\hline $\begin{array}{c}\text { CRM bottle } \\
\text { No }\end{array}$ & $\begin{array}{c}\text { Date } \\
\text { analyzed }\end{array}$ & $\begin{array}{c}\text { System Blank } \\
\mu \mathrm{gCC} / \mathrm{min}\end{array}$ & CALFAC & $\begin{array}{l}\text { Total } \mathrm{CO}_{2} \\
\mu \mathrm{mol} / \mathrm{kg}\end{array}$ \\
\hline 206 & 13.02 .91 & 0.050 & 1.004596 & 1977.1 \\
\hline 213 & 15.02 .91 & 0.058 & 1.004005 & 1977.8 \\
\hline 297 & 15.02 .91 & 0.058 & 1.004005 & 1976.9 \\
\hline 4 & 16.02 .91 & 0.034 & 1.009080 & 1979.6 \\
\hline 308 & 17.02 .91 & 0.018 & 1.003203 & 1977.8 \\
\hline 181 & 19.02 .91 & 0.034 & 1.003736 & 1977.6 \\
\hline 155 & 23.02 .91 & 0.036 & 1.002476 & 1977.6 \\
\hline 259 & 27.02 .91 & 0.038 & 1.004088 & 1979.2 \\
\hline 292 & 06.03 .91 & 0.031 & 1.004465 & 1978.3 \\
\hline 237 & 12.03.91 & 0.030 & 1.003876 & 1978.3 \\
\hline 156 & 20.03 .91 & 0.039 & 1.003915 & 1978.4 \\
\hline & & \multicolumn{2}{|c|}{ Mean standard deviation } & $1978.1 \pm 0.82$ \\
\hline
\end{tabular}

or expedited shipping procedures been worked out. Therefore, some of the differences in the seven completed comparisons listed in Table 2 probably resulted from unfamiliarity with the new RODAVISS glass bottle stoppers: some breakage was caused by overtightening; some loss of $\mathrm{CO}_{2}$, by undertightening of the stoppers. Nor were the storage conditions optimal for the data quality of the surviving samples: they were kept in a non-air-conditioned cargo hold for the remainder of R/V Meteor Cruise 15/3 and then transported to Brazil before they could be shipped to SIO. Temperature sensors were not included in the shipping crates, as is now standard operating procedure; however, temperatures likely exceeded an unacceptable $30^{\circ} \mathrm{C}$ in either the cargo hold during the R/V Meteor's return voyage to Brazil or in Brazil prior to shipment to SIO.

TALK samples were collected and poisoned with $50 \mu \mathrm{L}$ of saturated solution of $\mathrm{HgCl}_{2}$ in 250-mL, standard borosilicate glass, screw-cap bottles. They were stored at room temperature and returned to Woods Hole for TALK analysis. TALK was determined by potentiometric titration; a method derived from one first described by Dyrssen (1965) and later modified by Bradshaw et al. (1981) was used. The automated titration was performed in a closed cell maintained at constant temperature $\left(25 \pm 0.1^{\circ} \mathrm{C}\right)$; to be similar to seawater, the ionic strength of the hydrochloric 
acid solution $(0.1 \mathrm{~N})$ was adjusted with $\mathrm{NaCl}$. The ratio of the acid normality over the cell volume was calibrated before and after the sample analysis. The calibration consisted of preparing solutions of known TALK concentration and measuring them as described by Brewer et al. (1986). The precision of the measurements was estimated to be better than $0.1 \%$. The samples were likely exposed to relatively high temperatures during shipment from Brazil to Woods Hole. Some walle also broken during shipment. Overall precision of the data set was therefore slightly degraded from that expected from measurement error alone. The pooled standard deviation for ten replicate samples was $-0.12 \%$.

Table 2. Comparison of shipboard analyses of total carbon dioxide by coulometry (BNL) during $\mathrm{R} / \mathrm{V}$ Meteor Cruise 15/3 with the shore-based reference analyses by manometry on duplicate samples by C. D. Keeling, Scripps Institution of Oceanography (SIO).

\begin{tabular}{|c|c|c|c|c|c|c|c|}
\hline $\begin{array}{c}\text { Station } \\
\text { No }\end{array}$ & $\begin{array}{c}\text { Sample } \\
\text { date }\end{array}$ & $\begin{array}{c}\text { Niskin } \\
\text { No }\end{array}$ & $\begin{array}{c}\text { Depth } \\
\mathbf{m}\end{array}$ & $\begin{array}{c}\text { TCO } \\
\text { BNL } \\
\mu \mathrm{mol} / \mathrm{kg}\end{array}$ & $\begin{array}{c}\text { TCO } \\
\text { SIO } \\
\mu \mathrm{mol} / \mathrm{kg}\end{array}$ & $\begin{array}{c}\text { Diff. } \\
\text { BNL-SIO } \\
\mu \mathrm{mol} / \mathrm{kg}\end{array}$ & $\begin{array}{c}\text { Sal. Diff. } \\
\text { BNL-SIO } \\
\text { PSS }\end{array}$ \\
\hline 143 & 16.02 .91 & 318 & 1593 & 2174.21 & 2171.58 & +2.65 & +0.014 \\
\hline 143 & 16.02 .91 & 312 & 2995 & 2180.38 & 2183.44 & -3.06 & +0.020 \\
\hline 154 & 21.02 .91 & 224 & 8 & 2084.12 & 2095.58 & -11.46 & +0.045 \\
\hline 187 & 03.03 .91 & 224 & 7 & 2073.05 & 2075.58 & -2.53 & +0.013 \\
\hline 187 & 03.03 .91 & 318 & 1194 & 2212.87 & 2217.78 & -4.91 & +0.023 \\
\hline 187 & 03.03 .91 & 312 & 2492 & 2188.71 & 2183.74 & +4.97 & +0.034 \\
\hline 199 & 07.03 .91 & 202 & 898 & 2220.60 & 2228.38 & -7.78 & +0.007 \\
\hline
\end{tabular}

$\mathrm{pCO}_{2}$ was measured using an experimental analytical system employing a batch-equilibration, static headspace analysis technique, with detection by gas chromatography and a flame ionization detector. Subsequently, this technique has been greatly improved and a full description is presented by Neill et al. (1995). During the R/V Meteor Cruise 15/3, the developing technique gave less than optimum data quality for this parameter because not all sources of error were known. The data are presented primarily for completeness, and caution must be exercised in their quantitative interpretation.

Briefly, the technique used was based on the static headspace methane method of Johnson et al. (1990). Samples were collected in $60-\mathrm{mL}$ serum bottles rinsed and filled to overflowing at the Niskin bottle. These samples were transported to a box that was purged with a flow of 350 ppm $\mathrm{CO}_{2}$ in argon. A headspace of $\sim 5-\mathrm{mL}$ was introduced using a disposable pipette-tip attached to a special tool (Johnson et al. 1990). The headspace was purged briefly with the argon- $\mathrm{CO}_{2}$ mixture, and a septum was placed over the serum bottle neck and crimped tightly with an aluminum cap. Headspace overpressure from crimping was relieved by piercing the septum with a needle for 3 to 4 seconds. The samples were equilibrated for 4 to 6 hours in the dark in a shaking water bath at $20^{\circ} \mathrm{C}$. The experiments performed at sea indicated that there was no significant difference in the measured $\mathrm{pCO}_{2}$ of replicate samples equilibrated for periods from 2 
to 9 hours. Following equilibration, the septum was pierced with two needles. The longer needle was inserted to the bottom of the serum bottle to dispense a brine solution, while the shorter one penetrated just below the septum into the headspace. Approximately $4 \mathrm{~mL}$ of brine solution was injected into the bottle through the longer needle displacing the headspace through the shorter one to purge and fill a small $(400 \mu \mathrm{L})$ gas sample loop attached to the gas chromatograph. After filling, the loop was allowed to come to atmospheric pressure, temperature and pressure were recorded, and the contents were injected onto a $6 \mathrm{ft} \times 1 / 8$ in. stainless steel chromatographic column packed with Porapak N. A methanizer column containing a nickel catalyst (Varian Inc.) mounted in the injector block of the gas chromatograph at $325^{\circ} \mathrm{C}$ on the terminal end of the column was used to quantitatively convert $\mathrm{CO}_{2}$ to $\mathrm{CH}_{4}$ for detection by flame ionization. Carrier gas flow rate was $30 \mathrm{~mL} / \mathrm{min}$ of ultra high purity nitrogen; the methanizer was supplied with hydrogen from a hydrogen generator at $30 \mathrm{mU} / \mathrm{min}$. The flame ionization detector was supplied with compressed air and hydrogen at 300 and $30 \mathrm{~mL} / \mathrm{min}$, respectively.

The variety of septa used were found to leak during equilibration, after they had been pierced with needles. To calculate the partial pressure of $\mathrm{CO}_{2}$ after equilibration, it is usually necessary to measure or calculate the pressure of equilibration because of the phase redistribution of gases dissolved in seawater. Subsequent testing with a wide variety of septa and improved technique showed that the pressure of equilibration can be calculated or measured accurately when the septa do not leak. However, septa used during R/V Meteor Cruise 15/3 consistently leaked, so that the pressure of equilibration was the same as the ambient atmospheric pressure.

To calculate the $\mathrm{pCO}_{2}$ of the equilibrated samples, the area of the $\mathrm{CO}_{2}$ peak was converted to a mole fraction of $\mathrm{CO}_{2}$ within the headspace from temperature and pressure measurements, and a calibration curve was obtained from injections of gas-phase $\mathrm{CO}_{2}$ standards at nominal levels of $250,350,750$, and $1500 \mathrm{ppmv}$. Subsequently, these standards yere intercalibrated againgt primary standards maintained at the Lamont-Doherty Earth Observatory. 'The mole' fraction of $\mathrm{CO}_{2}$ at the measured atmospheric pressure was converted to the partial pressure of $\mathrm{CO}_{2}$ after equilibration. From the measured (unequilibrated) sample $\mathrm{TCO}_{2}$ (SOMMA), the original $\mathrm{CO}_{2}$ content of the introduced headspace, and the $\mathrm{CO}_{2}$ content after equilibration, the mass of $\mathrm{CO}_{2}$ transferred from the liquid to the gas phase, or vice versa, was calculated and used to the sample $\mathrm{TCO}_{2}$ / Calculate after equilibration. From $\mathrm{TCO}_{2}$ and the measured $\mathrm{pCO}_{2}$, the TALK was calculated. TALK was assumed to be conservative, and from the TALK-TCO 2 pair the $\mathrm{pCO}_{2}$ of the water sample at $20^{\circ} \mathrm{C}$ prior to equilibration was calculated by using the themodynamic constants of Roy et al. (1993), weiss (1874)

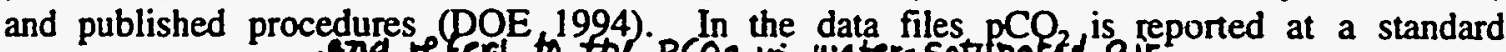
temperature of $20^{\circ} \mathrm{X}^{\circ}$ Actual equifibration temperatures generally ranged from $19.9^{\circ} \mathrm{C}$ to $20.2^{\circ} \mathrm{C}$.

Precision varied throughout the cruise, depending primarily on the status of the catalyst, that had to be reconditioned periodically. Precision on multiple $(>3)$ replicates varied from 0.4 to $\sim 6 \%$ and averaged $2 \%$. Accuracy was judged in three ways. First, throughout the cruise the mole fraction of $\mathrm{CO}_{2}$ in air was measured; air was collected in syringes at the bow of the ship during steaming between stations. The mean $\mathrm{pCO}_{2}$ of the air, expressed as a dry air mole fraction, was 353.6 ( \pm 9.74 ); this compares well with contemporary measurements of 353.5 and 352.9 made by the National Oceanic and Atmospheric Administration-Climate Monitoring and Diagnostics Laboratory air sampling network in February and March 1991 on air samples collected at Ascension Island $\left(7^{\circ} 55^{\circ} \mathrm{S}\right.$ and $14^{\circ} 25^{\circ} \mathrm{W}$ ) (Conway et al. 1994). This agreement suggested that although instrument imprecision was high, the overall accuracy of the measurements was consistent with a completely independent set of measurements. Second, assessment of accuracy arose from samples overdetermined for the carbonate system. In this case, the TALK by potentiometric titration for samples from two stations was compared with the TALK calculated from the measured $\mathrm{pCO}_{2}-\mathrm{TCO}_{2}$ pair. TALK calculated from the $\mathrm{pCO}_{2}-\mathrm{TCO}_{2}$ pair was $4 \mu \mathrm{mol} / \mathrm{kg}$ 
$( \pm 12)$ lower than the measured TALK for these stations. Once again, this suggested relatively good accuracy but poor precision. Third, overall assessment of accuracy was made by comparing the discrete- $\mathrm{pCO}_{2}$ measurements with measurements made by Lamont-Doherty Earth Observatory (LDEO). Station $199\left(19^{\circ} \mathrm{S}, 2^{\circ} \mathrm{W}\right)$ of Meteor Cruise 15/3 was compared with Station $144\left(20^{\circ}\right.$ $\left.\mathrm{S}, 1^{-} \mathrm{W}\right)$ of the SAVE expedition, at which a discrete-pCO $\mathrm{CO}_{2}$ profile had been collected during February 1988 by D. Chipman and T. Takahashi of LDEO. The respective profiles show very good agreement within the Angola Basin Deep Waters $(>2000 \mathrm{~m}$ ) (Fig. 4). For this depth range, the $\mathrm{R} / \mathrm{V}$ Meteor $15 / 3$ mean value of $\mathrm{pCO}_{2}$ at $20^{\circ} \mathrm{C}$ was $801( \pm 10)$ compared with a SAVE value of $786( \pm 11)$. In the upper waters, systematic differences were noted between the two profiles; however, these can be seen in the $\mathrm{TCO}_{2}$ data as well.

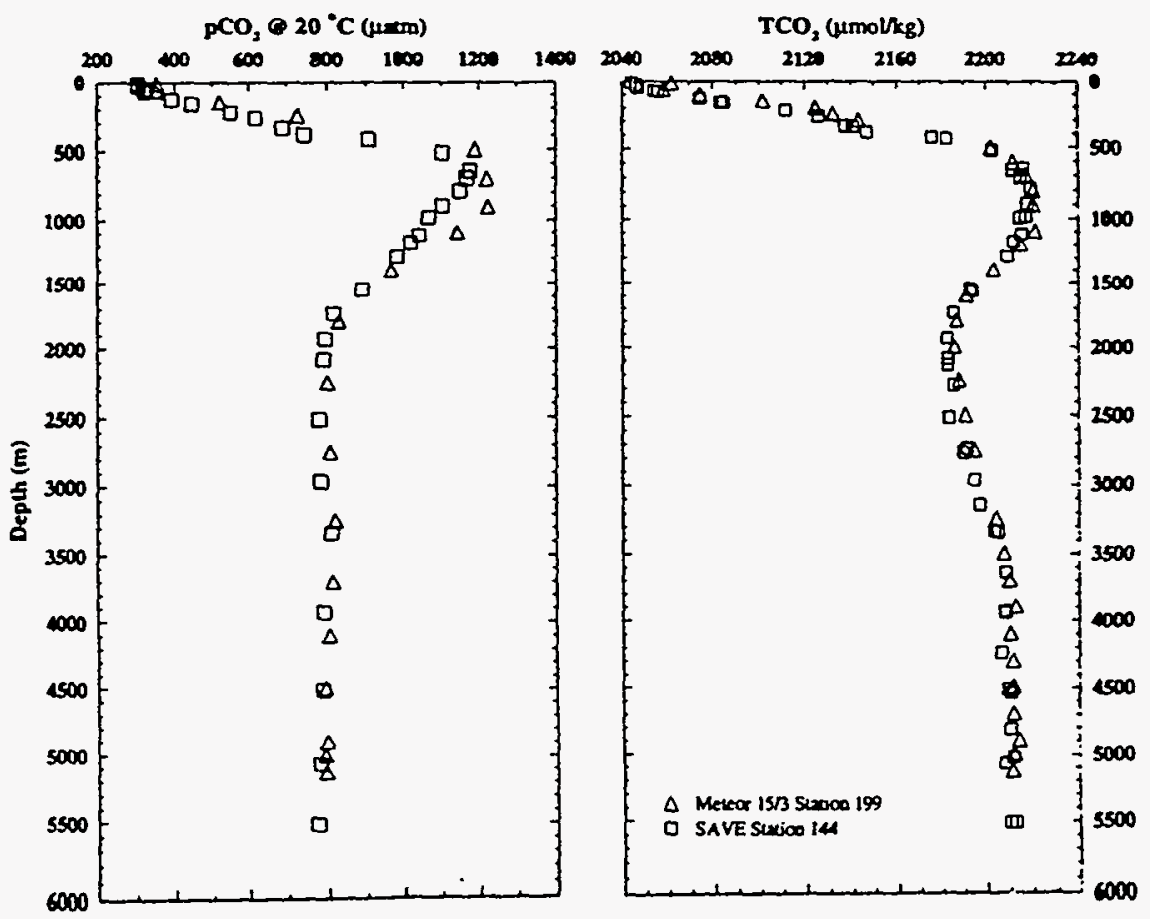

Figure 4. Comparison of discrete partial pressure of carbon dioxide and total carbon dioxide profiles at Station 199 of R/V Meteor Cruise 15/3 (March 1991) to those from South Atlantic Ventilation Experiment Station 144 (February 1988).

Exploratory measurements of anthropogenic halocarbon compounds $\left[\mathrm{CCl}_{4}, \mathrm{CCl}_{2} \mathrm{FCCIF}_{2}\right.$ (CFC-113), $\mathbf{C C l}_{3} \mathbf{F}$ (CFC-11), and $\mathrm{CCl}_{2} \mathrm{~F}_{2}$ (CFC-12)] were made using a new analytical technique on R/V Meteor Cruise 15/3 (Wallace et al. 1994). The new method was jointly developed by BNL, Bedford Institute of Oceanography (Canada), and Chalmers University of Technology (Sweden). Briefly, it employs a purge-and-trap extraction technique similar to that used in previous CFC analysis systems (Gammon et al. 1982; Wallace and Moore 1985; Bullister and Weiss 1988). The most significant differences/wefe: the ewlier techrvique 
1. The chromatographic column used was a wide-bore DB-624 glass capillary (J\&W; $70 \mathrm{~m} \times$ $0.53 \mathrm{~mm}$ OD; 3- $\mu \mathrm{m}$ film) which gives baseline resolution between the tracer compounds of interest and a variety of natural and anthropogenic halocarbons.

2. The purged volatile compounds were trapped on a short Porapak $N$ column kept at ambient temperature $\left(-20^{\circ} \mathrm{C}\right)$. This eliminated the need for taking cryogenic systems to sea. Because CFC- 11 and CFC-12 were measured separately the system was optimized for measuring low levels of $\mathrm{CCl}_{4}, \mathrm{CH}_{3} \mathrm{CCl}_{3}$, and CFC- 113 by using a 20 -mL water sample and increasing the purge-gas flow to $5 \mathrm{~min}$ at $60 \mathrm{~mL} / \mathrm{min}$. Extraction efficiency was $>99 \%$ for all compounds except $\mathrm{CH}_{3} \mathrm{CCl}_{3}$ ( $\left.\sim 85 \%\right)$. These conditions caused $\mathrm{CFC}-12$ to approach breakthrough on the trap, decreasing precision and accuracy for this compound. Hence, all CFC-12 (and most CFC-11) data in this NDP are based on measurements obtained by using the separate packed column system, which employed low-temperature trapping.

Two unexpected problems were encountered: a partial chromatographic interference for CFC113 due to extremely high levels of $\mathrm{CH}_{3} \mathrm{I}$ in tropical near-surface waters and a second, more serious problem, arising from a buildup of water on the column, which caused large negative have sibsequertly peaks and an interfering baseline shift in the vicinity of the CFC-113 peak. Both of these problems colrected; however, they greatly reduced the number of samples that could be obtained. 


\section{DATA CHECKS AND PROCESSING PERFORMED BY CDIAC}

An important part of the NDP process at the Carbon Dioxide Information Analysis Center (CDIAC) involves the quality assurance (QA) of data before distribution. Data received at CDIAC are rarely in a condition that would permit immediate distribution, regardless of the source. To guarantee data of the highest possible quality, CDIAC conducts extensive QA reviews that involve examining the data for completeness, reasonableness, and accuracy. Although they have common objectives, these reviews are tailored to each data set, often requiring extensive programming efforts. In short, the QA process is a critical component in the value-added concept of supplying accurate, usable data for researchers.

The following summarizes the data-processing and QA checks performed by CDIAC on the data obtained during the R/V Meteor Expedition 15/3 in the South Atlantic Ocean.

1. Carbon-related data and preliminary hydrographic measurements were provided to CDIAC by $\mathrm{K}$. M. Johnson and D. W. R. Wallace of BNL. The final hydrographic and chemical measurements and the station information files were provided by the WOCE Hydrographic Program Office (WHPO) after quality evaluation. A FORTRAN 77 retrieval code was written and used to merge and reformat all data files.

?2 2. To check for obvious outliers, all data were plotted by use of a PLOTNEST.C program written by Stewart C. Sutherland (LDEO). The program plots a series of nested profiles, using the station number as an offset; the first station is defined at the beginning, and subsequent stations are offset by a fixed interval (Figs. 5 and 6). Several outliers were identified and removed after consultation with the principal investigators.

3. To identify "noisy" data and possible systematic, methodological errors, property-property plots for all parameters were generated (Fig. 7), carefully examined, and compared with plots from previous expeditions in the South Atlantic Ocean.

4. All variables were checked for values exceeding physical limits, such as sampling depth values that are greater than the given bottom depths.

5. Dates, times, and coordinates were checked for bogus values (e.g., values of MONTH $<1$ or $>12$; DAY < 1 or $>31$; YEAR $<$ or $>1991$; TIME $<0000$ or $>2400$; LAT $<-25.000$ or $>17.000$; and LONG $<-40.000$ or $>12.000$ ).

6. Station locations (latitudes and longitudes) and sampling times were examined for consistency with maps and with cruise information supplied by $K$. M. Johnson and D. W. R. Wallace, BNL.

7. The designation for missing values, given as -9.0 in the original files, was changed to -999.9 . 


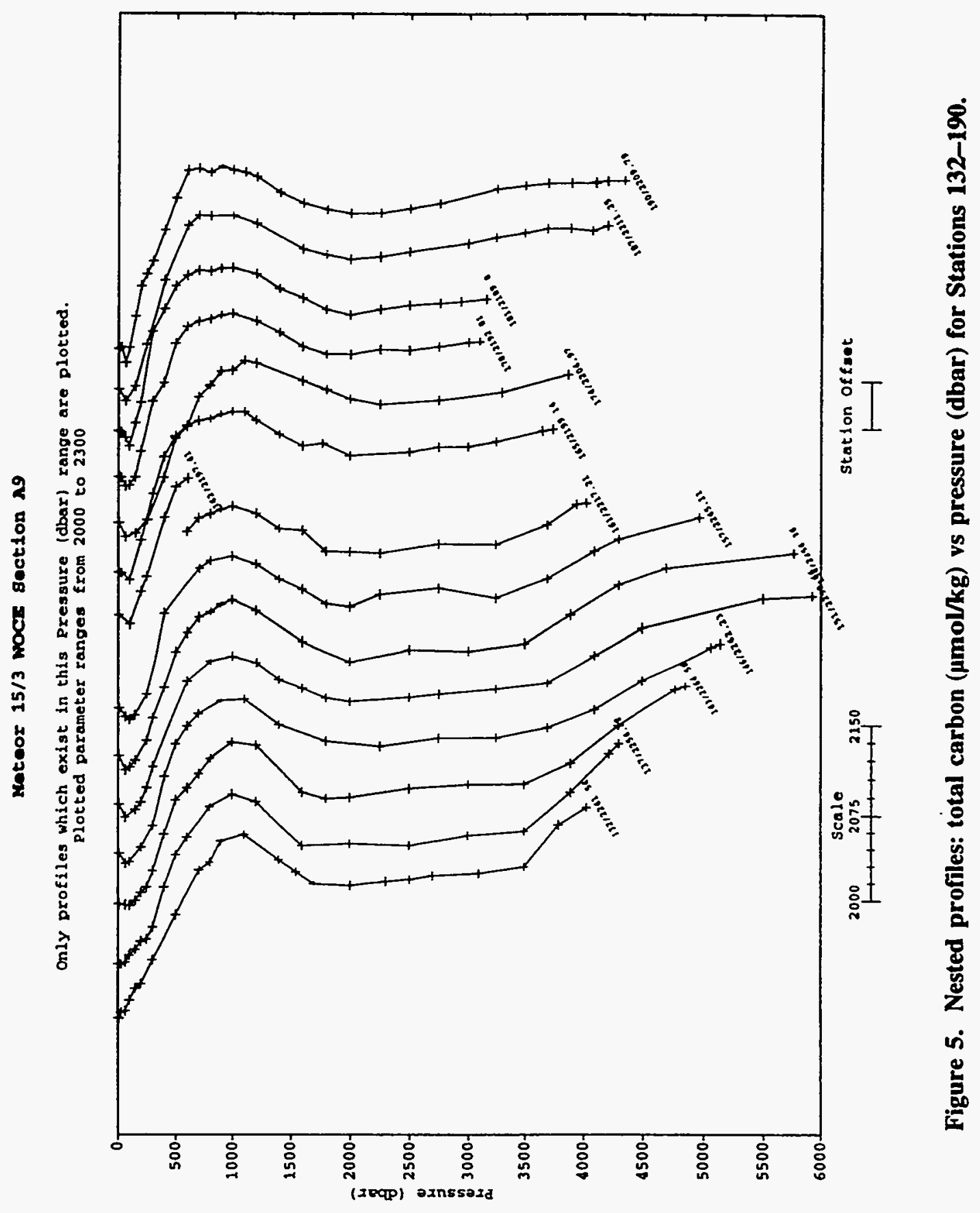




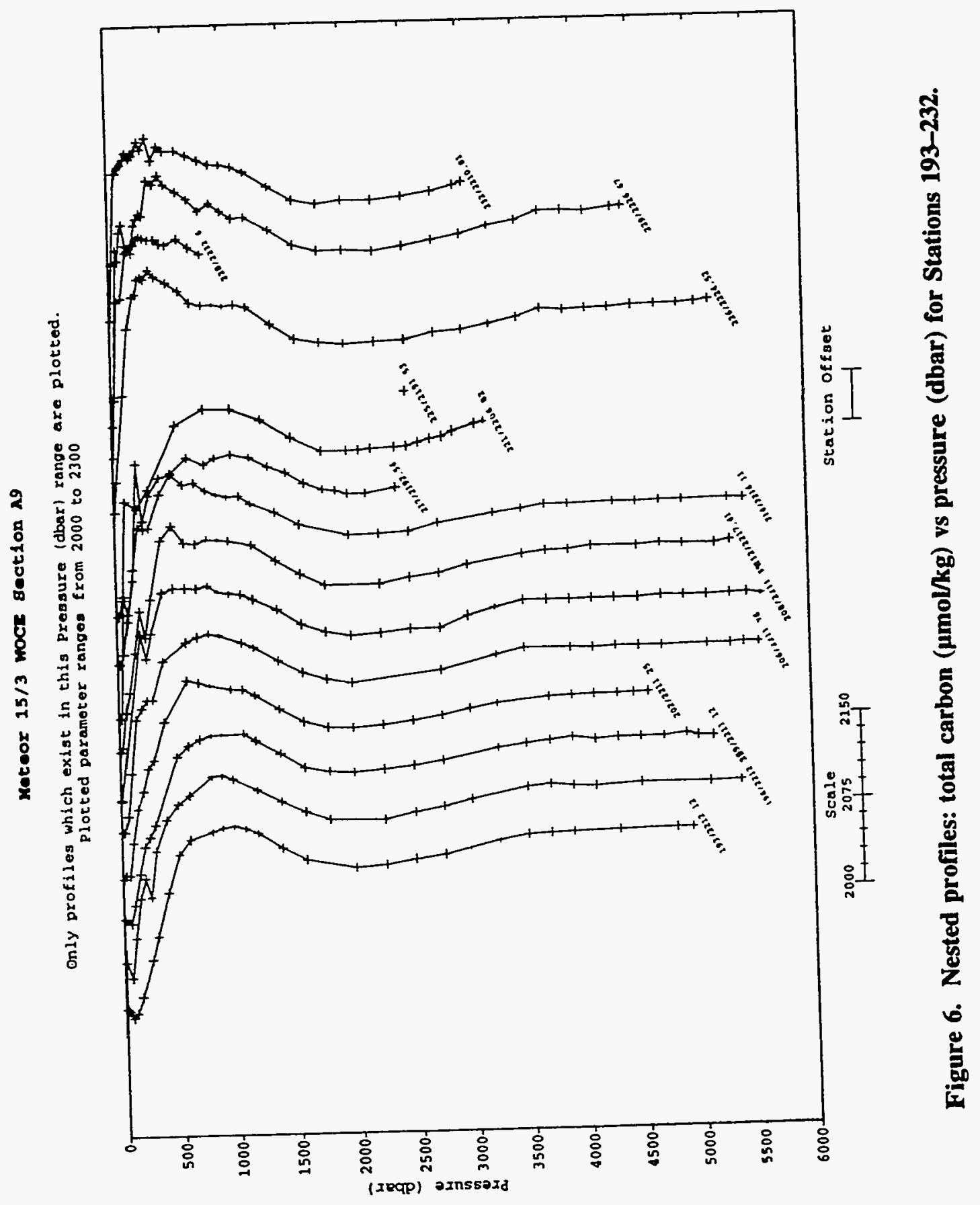



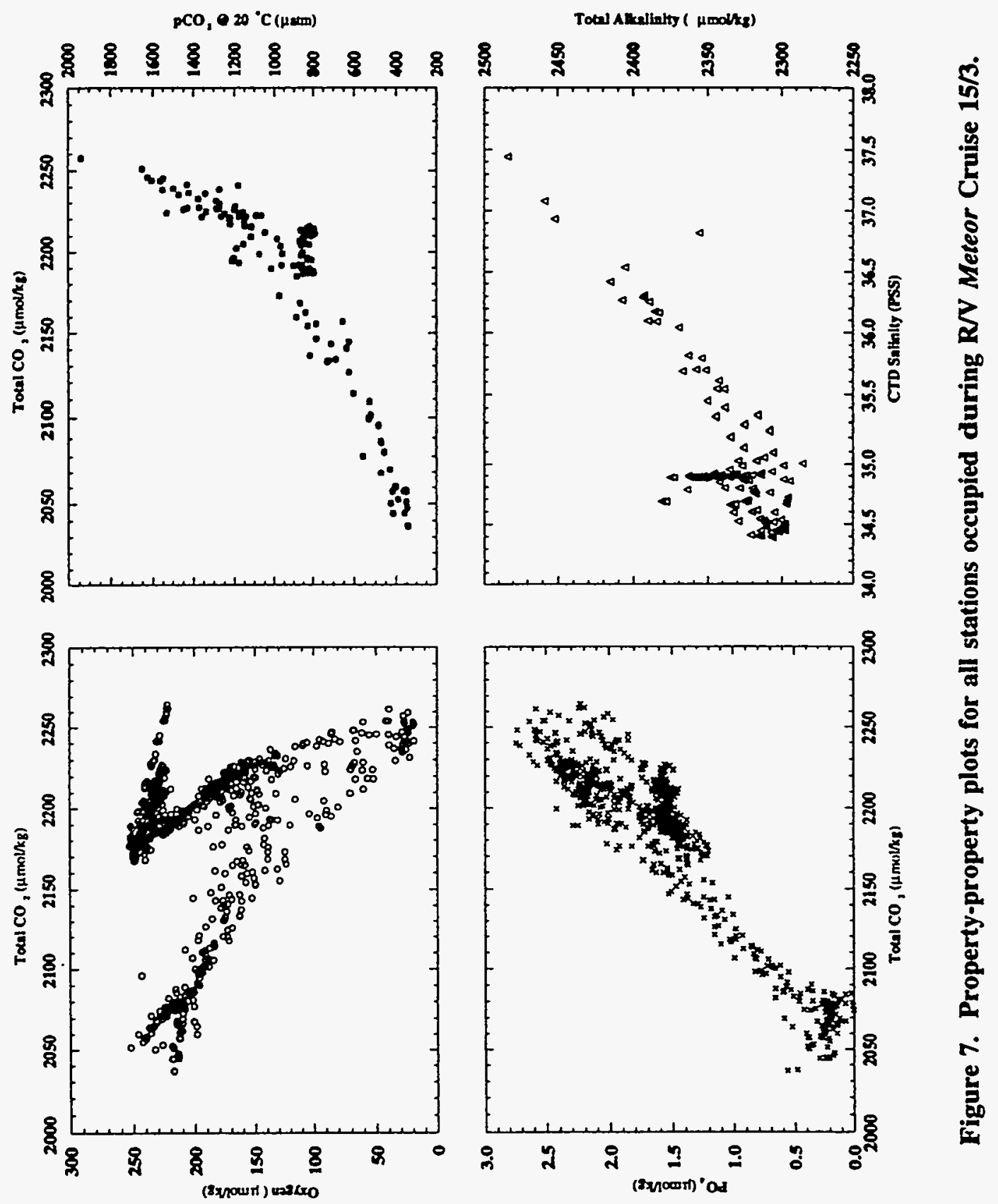


\section{HOW TO OBTAIN THE DATA AND DOCUMENTATION}

This database is available on request in machine-readable form, without charge, from CDIAC. CDIAC will also distribute subsets of the database as needed. It can be acquired on 9-track magnetic tape; 8-mm tape; 150-mB, quarter-inch tape cartridge; IBM-formatted floppy diskettes; or from CDIAC's anonymous File Transfer Protocol (FTP) area via Internet (see FTP address below). Requests should include any specific media instructions (e.g., 1600 or $6250 \mathrm{BPI}$, labeled or nonlabeled, ASCII or EBCDIC characters, and variable- or fixed-length records; 3.5- or 5.25inch floppy diskettes, high or low density; and 8200 or 8500 format, 8 -mm tape) required by the user to access the data. Magnetic tape requests not accompanied by specific instructions will be filled on 9-track, 6250-BPI, standard-labeled tapes with EBCDIC characters. Requests should be addressed to

Carbon Dioxide Information Analysis Center

Oak Ridge National Laboratory

Post Office Box 2008

Oak Ridge, Tennessee 37831-6335

U.S.A.

Telephone: (615) 574-0390 or (615) 574-3645

Fax: $\quad$ (615) $574-2232$

Electronic Mail: INTERNET: CDIAC@ORNL.GOV

The data files can also be acquired from CDIAC's anonymous FTP account via Internet:

- FTP to cdiac.esd.ornl.gov (128.219.24.36),

- Enter "ft" or "anonymous" as the user $\mathrm{DD}$,

- Enter your electronic mail address as the password (e.g.,"alex@.esd.ornl.gov")',

- Change to the directory "/pub/ndp051", and

- Acquire the files using the FTP "get" or "mget" command.

'Please enter your correct address. This address is used by CDIAC to inform data recipients of data revisions and updates. 


\section{D \\ 6. REFERENCES}

Bradshaw A. L., P. G. Brewer, K. K. Shafer, and R. T. Williams. 1981. Measurements of total carbon dioxide and alkalinity by potentiometric titration in the GEOSECS program. Earth Planet. Sci. Lett., 55:99-115.

Brewer, P. G., C. Goyet, and D. Dyrssen. 1989. Carbon dioxide transport by ocean currents at $25^{\circ} \mathrm{N}$ latitude in the Atlantic Ocean. Science 246:477-79.

Brewer, P. G., A. L. Bradshaw, and R. T. Williams. 1986. Measurements of total carbon dioxide and alkalinity in the North Atlantic Ocean in 1981. pp. 358-81. In D. Reiche (ed.), The Global Carbon Cycle: Analysis of the Natural Cycle and Implications of Anthropogenic Alterations for the Next Century. Springer, New York.

Bryden, H. L., and M. M. Hall. 1980. Heat transport by ocean currents across $25^{\circ} \mathrm{N}$ latitude in the North Atlantic Ocean. Science 207:884.

Bullister, J. L., and R. F. Weiss. 1988. Determination of $\mathrm{CCl}_{3} \mathrm{~F}$ and $\mathrm{CCl}_{2} \mathrm{~F}_{2}$ in seawater and air. Deep Sea Res. 35:839-53.

Conway, J. J., P. P. Tans, and L. S. Waterman. 1994. Atmospheric $\mathrm{CO}_{2}$ records from sites in the NOAA/CMDL air-sampling network. pp. 41-119. In T. A. Boden, D. P. Kaiser, R. J. Sepanski, and F. W. Stoss (eds.), Trends '93: A compendium of data on global change. ORNL/CDIAC-65. Oak Ridge National Laboratory.

DOE (U.S. Department of Energy). 1994. Handbook of methods for the analysis of the various parameters of the carbon dioxide system in sea water. Ver. 2. ORNL/CDIAC-74. A. G. Dickson and C. Goyet (eds.). Oak Ridge National Laboratory.

Dyrssen D. 1965. A gran titration of sea water on board SAGITTA. Acta Chemica Scand. 19:1265.

Gammon, R. N., J. Cline, and D. P. Wisegarver. 1982. Chlorofluoromethanes in the northeast Pacific Ocean: Measured vertical distribution and application as transient tracers of upper ocean mixing. J. Geophys. Res. 87:9441-54.

Grasshoff, K., M. Ehrhardt, and K. Kremling (eds.). 1983. Methods of Seawater Analysis, 2d ed. Verlag Chemie GmbH, Weinheim, Germany. 419.

Guenther, P. R., C. D. Keeling, and G. Emanuele III. 1994. Oceanic $\mathrm{CO}_{2}$ Measurements for the WOCE Hydrographic Survey in the Pacific Ocean, 1990-1991: Shore Based Analyses. SIO Reference Series. Ref. No. 94-28, University of California.

Johnson, K. M. and D. W. R. Wallace. 1992. The single-operator multiparameter metabolic analyzer for total carbon dioxide with coulometric detection. DOE Research Summary, No. 19. Carbon Dioxide Information Analysis Center, Oak Ridge National Laboratory. 
Johnson, K. M., A. E. King, and J. McN. Sieburth. 1985. Coulometric $\mathrm{TCO}_{2}$ analyses for marine studies: An introduction. Mar. Chem. 16:61-82.

Johnson, K. M., J. M. Sieburth, P. J. B. Williams, and L. Brändström. 1987. Coulometric $\mathrm{TCO}_{2}$ analysis for marine studies: Automation and calibration. Mar. Chem. 21:117-33.

Johnson, K. M., J. E. Hughes, P. L. Donaghay, and J. McN. Sieburth. 1990. Bottle-calibration static head space method for the determination of methane dissolved in seawater. Anal. Chem. 62:2408-12.

Johnson, K. M., K. D. Wills, D. B. Butler, W. K. Johnson, and C. S. Wong. 1993. Coulometric total carbon dioxide analysis for marine studies: Maximizing the performance of an automated gas extraction system and coulometric detector. Mar. Chem. 44:167-87.

Millero, F. J., and A. Poisson. 1981. International one-atmosphere equation of state for sea water. Deep-Sea Res. 28:625-29.

Moore B. and B. H. Braswell, Jr. 1994. Planetary Metabolism: Understanding the Carbon Cycle, MBIO Vol. 23, No. 1. Royal Swedish Academy of Sciences, Sweden.

Neill, C., D. W. R. Wallace, and K. M. Johnson. 1995. Small volume, batch equilibration measurement of $\mathrm{pCO}_{2}$ in discrete water samples. Deep-Sea Research (submitted).

Roemmich, D., and C. Wunsch. 1985. Two transatlantic sections: Meridional circulation and heat flux in the subtropical North Atlantic Ocean. Deep-Sea Res. 32:619-64.

Roy, R. N., L. N. Roy, M. Lawson, K. M. Vogel, C. P. Moore, W. Davis, and F. J. Millero. 1993. Thermodynamics of the dissociation of boric acid in seawater at $S=35$ from 0 to $55^{\circ} \mathrm{C}$. Mar. Chem. 44:243-48.

Ruhsam, C. M. 1994. WHP One-Time Section A9 Data Report. WOCE Special Analysis Center, Bundesamt feur Seeschiffahrt and Hydrographie, Hamburg (unpublished manuscript).

Siedler, G., and W. Zenk. 1992. WOCE Sudatlantik 1991, Reise Nr. 15, 30 Dezember 1990-23 Marz 1991. METEOR-Berichte. Universitat Hamburg, 92-1.

Wallace, D. W. R., and R. M. Moore. 1985. Vertical profiles of $\mathrm{CCl}_{2} \mathrm{~F}_{2}(\mathrm{~F}-12)$ and $\mathrm{CCl}_{3} \mathrm{~F}(\mathrm{~F}-11)$ in the Central Arctic Ocean Basin. J. Geophys. Res. 90:1155-66.

Wallace, D. W. R., P. Beining, and A. Putzka. 1994. Carbon tetrachloride and chlorofluorocarbons in the South Atlantic Ocean, 19 S. J. Geophys. Res. 99:7803-19.

Wilke, R. J., D. W. R. Wallace, and K. M. Johnson. 1993. A water-based, gravimetric method for the determination of gas sample loop volume. Anal. Chem. 65:2403-06.

Youden, W. J. 1951. Statistical Methods for Chemists. Wiley, New York.

$$
\begin{aligned}
& \text { Weiss, R.F. 1974. Carbon dioxide mi water and seawator: the } \\
& \text { solubility of a non-ideal gas, Mar.Chem. 2: 203-15. }
\end{aligned}
$$


PART 2

\section{CONTENT AND FORMAT OF DATA FILES}




\section{FILE DESCRIPTIONS}

This section describes the content and format of each of the five files that comprise this NDP (see Table 3). Because CDIAC distributes the data set in several ways (e.g., via anonymous FTP, floppy diskette, and on 9-track magnetic tape), each of the five files is referenced by both an ASCII file name, which is given in lower-case, bold-faced type (e.g., readme) and a file number. The remainder of this section describes (or lists, where appropriate) the contents of each file. The files are discussed in the order in which they appear on the magnetic tape.

Table 3. Content, size, and format of data files

File number, name, and description
Logical

records
File size

in bytes

Block

Record size length

1. readme:

450

48,004

8,000

80

a detailed description

of the cruise network, the two FORTRAN 77 data

retrieval routines, and the

two oceanographic data

files

2. stainv.for:

33

1,195

8,000

80

a FORTRAN 77 data retrieval routine to read and print

m153sta.inv (File 4)

3. m153dat.for:

a FORTRAN 77 data retrieval

49

2,278

8,000

80

routine to read and print

met153.dat (File 5)

4. m153sta.inv:

15,405

4,100

41

a listing of the station locations, sampling dates, and sounding bottom depths for each of the 111 stations

5. met153.dat:

hydrographic, carbon dioxide, and chemical data from 111 stations

Total

$\mathbf{4 , 4 3 3 \quad 8 7 8 , 4 9 6}$




\section{readme (File 1)}

This file contains a detailed description of the data set, the two FORTRAN 77 data retrieval routines, and the two oceanographic data files. It exists primarily for the benefit of individuals who acquire this database as machine-readable data files from CDIAC.

\section{stainv.for (File 2)}

This file contains a FORTRAN 77 data retrieval routine to read and print m153sta.inv (File 4). The following is a listing of this program. For additional information regarding variable definitions, variable lengths, variable types, units, and codes, please see the description for m153sta.inv.

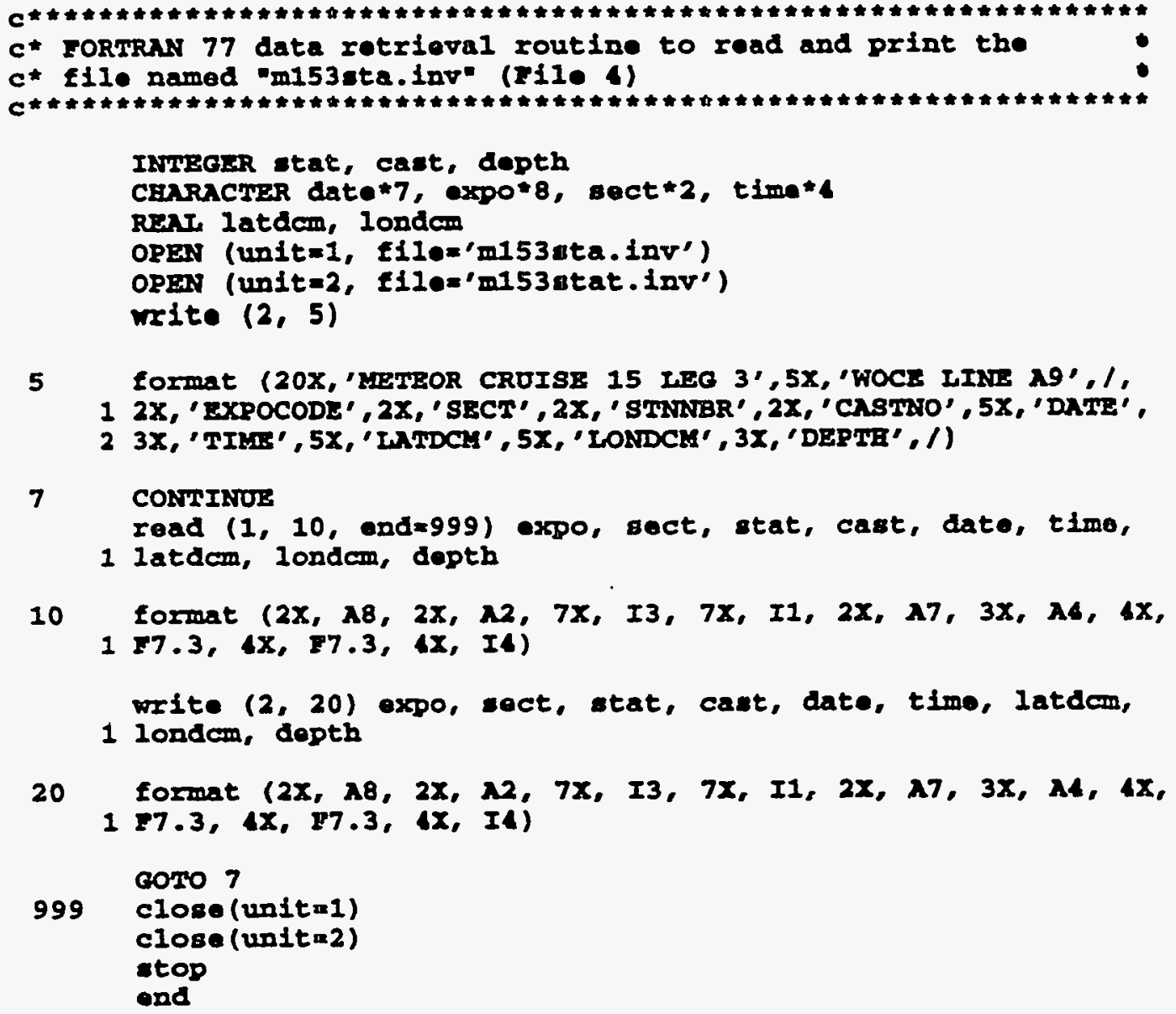




\section{m153sta.inv (File 4)}

This file provides station inventory information for each of the 111 stations occupied during R/V Meteor Cruise 15/3. Each line of the file contains an expocode, section number, station number, cast number, sampling date, sampling time, latitude, longitude, and sounding depth. The file is sorted by station number and can be read by using the following FORTRAN 77 code (contained in stainv.for, File 2):

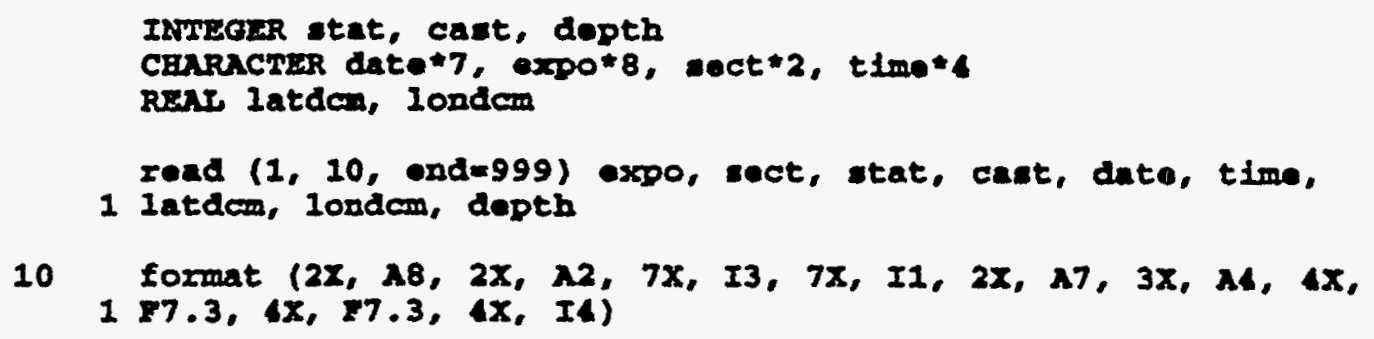

Stated in tabular form, the contents include the following:

\begin{tabular}{llccc}
\hline Variable & $\begin{array}{l}\text { Variable } \\
\text { type }\end{array}$ & $\begin{array}{c}\text { Variable } \\
\text { width }\end{array}$ & $\begin{array}{c}\text { Starting } \\
\text { column }\end{array}$ & $\begin{array}{c}\text { Ending } \\
\text { column }\end{array}$ \\
\hline expo & Character & 8 & 3 & 10 \\
sect & Character & 2 & 13 & 14 \\
stat & Numeric & 3 & 22 & 24 \\
cast & Numeric & 1 & 32 & 32 \\
date & Character & 7 & 35 & 41 \\
time & Character & 4 & 45 & 48 \\
latdcm & Numeric & 7 & 53 & 59 \\
londcm & Numeric & 7 & 64 & 70 \\
depth & Numeric & 4 & 75 & 78 \\
\hline
\end{tabular}

where

expo is the expocode of the cruise;

sect is the WOCE section number;

stat is the station number (values range from 122 to 232);

cast is the cast number;

date is the sampling date (includes: month/day/year); 
time $\quad$ is the sampling time (GMT);

latdcm is the latitude of the station (in decimal degrees; negative values indicate the Southern Hemisphere);

londcm is the longitude of the station (in decimal degrees; negative values indicate the Western Hemisphere);

depth is the sounding depth of the station (in meters).

\section{met153.dat (File 5)}

This file provides hydrographic, carbon dioxide, and chemical data for the 111 stations occupied during R/V Meteor Cruise 15/3. Each line consists of a station number; cast number; sample number; bottle number; CTD pressure, temperature, salinity, and oxygen; potential temperature; bottle salinity; concentrations of oxygen, silicate, nitrate, nitrite, phosphate, total carbon dioxide, and total alkalinity; $\mathrm{pCO}_{2} ; \mathrm{pCO}_{2}$ temperature; CFC-113; CCl 4 CFC-12; CFC-11; and data quality flags. The file is sorted by station number and pressure and can be read by using the following FORTRAN 77 code (contained in m153dat.for, File 3):

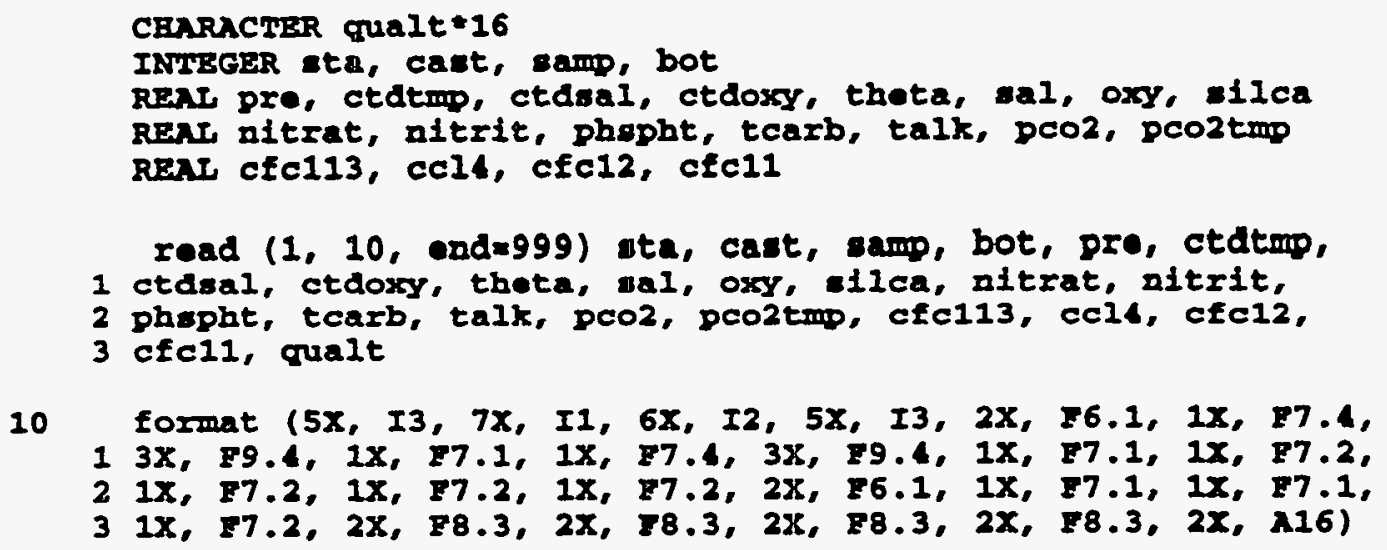

Stated in tabular form, the contents include the following:

\begin{tabular}{llccc}
\hline Variable & $\begin{array}{c}\text { Variable } \\
\text { type }\end{array}$ & $\begin{array}{c}\text { Variable } \\
\text { width }\end{array}$ & $\begin{array}{c}\text { Starting } \\
\text { column }\end{array}$ & $\begin{array}{c}\text { Ending } \\
\text { column }\end{array}$ \\
\hline sta & Numeric & 3 & 6 & 8 \\
cast & Numeric & 1 & 16 & 16 \\
samp & Numeric & 2 & 23 & 24 \\
bot & Numeric & 3 & 30 & 32 \\
pre & Numeric & 6 & 35 & 40 \\
ctdtmp & Numeric & 7 & 42 & 48
\end{tabular}




\begin{tabular}{lllll} 
ctdsal & Numeric & 9 & 52 & 60 \\
ctdoxy & Numeric & 7 & 62 & 68 \\
theta & Numeric & 7 & 70 & 76 \\
sal & Numeric & 9 & 80 & 88 \\
oxy & Numeric & 7 & 90 & 96 \\
silca & Numeric & 7 & 98 & 104 \\
nitrat & Numeric & 7 & 106 & 112 \\
nitrit & Numeric & 7 & 114 & 120 \\
phspht & Numeric & 7 & 122 & 128 \\
tcarb & Numeric & 6 & 131 & 136 \\
talk & Numeric & 7 & 138 & 144 \\
pco2 & Numeric & 7 & 146 & 152 \\
pco2tmp & Numeric & 7 & 154 & 160 \\
cfc113 & Numeric & 8 & 163 & 170 \\
ccl4 & Numeric & 8 & 173 & 180 \\
cfc12 & Numeric & 8 & 183 & 190 \\
cfc11 & Numeric & 8 & 193 & 200 \\
qualt & Character & 16 & 203 & 218 \\
\hline
\end{tabular}

where

\begin{tabular}{|c|c|}
\hline sta & is the station number; \\
\hline cast & is the cast number; \\
\hline samp & is the sample number; \\
\hline bot $^{*}$ & is the bottle number; \\
\hline pre & is the CTD pressure (in dbar); \\
\hline ctdtmp & is the CTD temperature (in ${ }^{\circ} \mathrm{C}$ ); \\
\hline ctdsal $^{\bullet}$ & is the CTD salinity [in Practical Salinity Scale (PSS)]; \\
\hline ctdoxy & is the CTD oxygen (in $\mu \mathrm{mol} / \mathrm{kg}$ ); \\
\hline theta & is the potential temperature (in ${ }^{\circ} \mathrm{C}$ ); \\
\hline sal $^{*}$ & is the bottle salinity (in PSS); \\
\hline $\mathbf{o x y} \mathbf{0}^{\bullet}$ & is the oxygen concentration (in $\mu \mathrm{mol} / \mathrm{kg}$ ); \\
\hline silca & is the silicate concentration (in $\mu \mathrm{mol} / \mathrm{kg}$ ); \\
\hline nitrat & is the nitrate concentration (in $\mu \mathrm{mol} / \mathrm{kg}$ ); \\
\hline
\end{tabular}




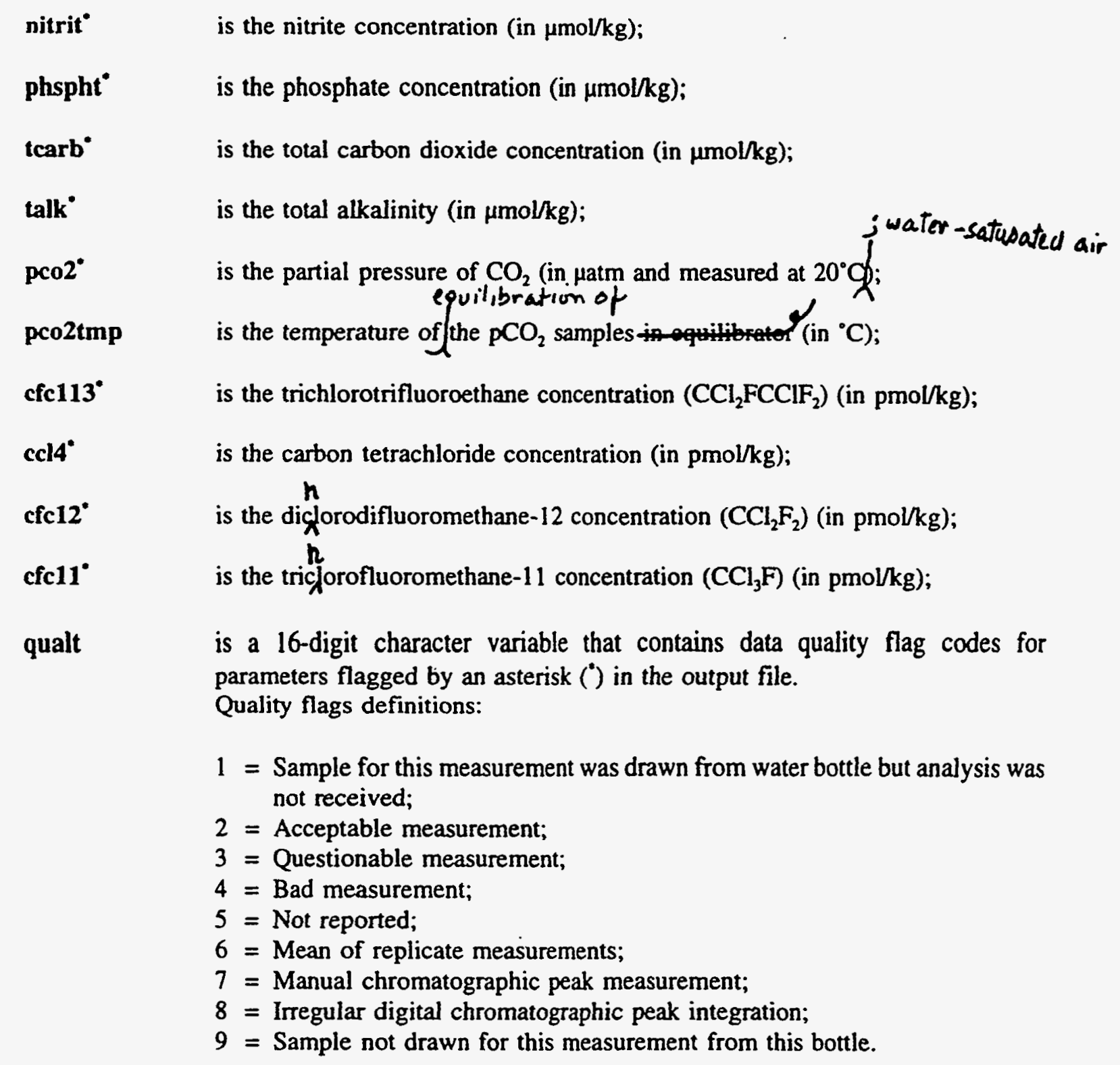




\section{VERIFICATION OF DATA TRANSPORT}

The data files contained in this numeric data package can be read by using the FORTRAN 77 data retrieval programs provided. Users should visually examine each data file to verify that the data were correctly transported to their systems. To facilitate the visual inspection process, partial listings of each data file are provided in Tables 4 and 5 . Each of these tables contains the first and last five lines of a data file. 
Table 4. Partial listing of "m153sta.inv" (File 4)

First five lines of the file:

$\begin{array}{lll}06 x y 15 / 3 & 19 & 122 \\ 06 x+15 / 3 & 19 & 122 \\ 06 x y 15 / 3 & 19 & 123 \\ 06 x+15 / 3 & 19 & 124 \\ 06 x \times 15 / 3 & 19 & 125\end{array}$

$\begin{array}{llll}1 & 2 / 11 / 91 & 1021 & -19.000 \\ 2 & 2 / 11 / 91 & 1339 & -19.005 \\ 1 & 2 / 11 / 91 & 1813 & -19.005 \\ 1 & 2 / 11 / 91 & 2158 & -19.000 \\ 1 & 2 / 12 / 91 & 0217 & -19.002\end{array}$

$\begin{array}{ll}-37.423 & 3514 \\ -37.430 & 3510 \\ -37.590 & 3370 \\ -37.672 & 3376 \\ -37.750 & 2354\end{array}$

Last five lines of the file:

\begin{tabular}{|c|c|c|c|c|c|c|c|c|}
\hline $\begin{array}{l}06 x+15 / 3 \\
06 x+15 / 3 \\
06 x+15 / 3 \\
06 x+15 / 3 \\
06 x+15 / 3\end{array}$ & $\begin{array}{l}\lambda 9 \\
\lambda 9 \\
\lambda 9 \\
\lambda 9 \\
\lambda\end{array}$ & $\begin{array}{l}230 \\
231 \\
231 \\
232 \\
232\end{array}$ & $\begin{array}{l}2 \\
1 \\
2 \\
1 \\
2\end{array}$ & $\begin{array}{l}3 / 18 / 91 \\
3 / 18 / 91 \\
3 / 18 / 91 \\
3 / 18 / 91 \\
3 / 18 / 91\end{array}$ & $\begin{array}{l}0532 \\
1056 \\
1218 \\
1931 \\
2051\end{array}$ & $\begin{array}{l}-18.072 \\
-17.018 \\
-17.018 \\
-17.025 \\
-17.025\end{array}$ & $\begin{array}{l}10.007 \\
10.483 \\
10.483 \\
10.807 \\
10.805\end{array}$ & $\begin{array}{l}4124 \\
3590 \\
3598 \\
3047 \\
3045\end{array}$ \\
\hline
\end{tabular}


Table 5. Partial listing of "met153.dat" (File 5)

First five lines of the file:

\begin{tabular}{|c|c|c|c|c|c|c|c|c|}
\hline 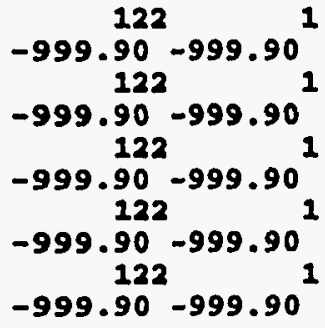 & $\begin{array}{l}-999.9^{1} \\
-999.9^{2} \\
-999.9^{3} \\
-999.9^{6} \\
-999.9^{5}\end{array}$ & $\begin{array}{c}324 \\
-999.9 \\
323 \\
-999.9 \\
322 \\
-999.9 \\
321 \\
-999.9 \\
320 \\
-999.9\end{array}$ & $\begin{array}{l}2998.02 .6299 \\
-999.9-999.90 \\
2998.022 .6299 \\
-999.9-999.90 \\
2998.022 .6299 \\
-999.9-999.90 \\
2998.02 .6299 \\
-999.9-999.90 \\
2998.022 .6299 \\
-999.9-999.90\end{array}$ & $\begin{array}{c}34.9159 \\
-999.900 \\
34.9159 \\
-999.900 \\
34.9159 \\
-999.900=\overline{34.9159} \\
39.900 \\
34.9159 \\
-999.900\end{array}$ & $\begin{array}{l}9 \\
-999.900 \\
9 \quad-999.9 \\
-999.900 \\
9 \quad 254.2 \\
-999.900 \\
9 \quad-999.9 \\
-999.900 \\
9 \quad 254.2 \\
-999.900\end{array}$ & $\begin{array}{l}2.3874 \\
0.000 \\
2.3874 \\
0.001 \\
2.3874 \\
-0.004 \\
2.3874 \\
-0.004 \\
2.3874 \\
-0.001\end{array}$ & $\begin{aligned} 34.9150 \\
0.088 \\
34.9140 \\
0.017 \\
34.9150 \\
0.112 \\
34.9150 \\
0.008 \\
34.9160 \\
0.007\end{aligned}$ & $\begin{array}{l}253.5-999.90-999.90 \\
2222299999999923 \\
254.5-999.90-999.90 \\
2292299999999923 \\
253.0-999.90-999.90 \\
2222299999999923 \\
254.0-999.90-999.90 \\
2292299999999922 \\
254.3-999.90-999.90 \\
2222299999999922\end{array}$ \\
\hline
\end{tabular}

Last five lines of the file:

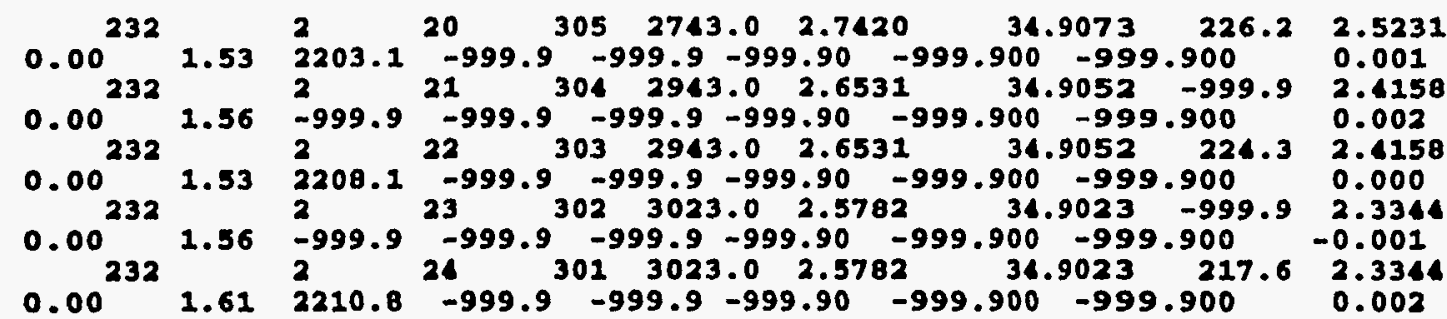

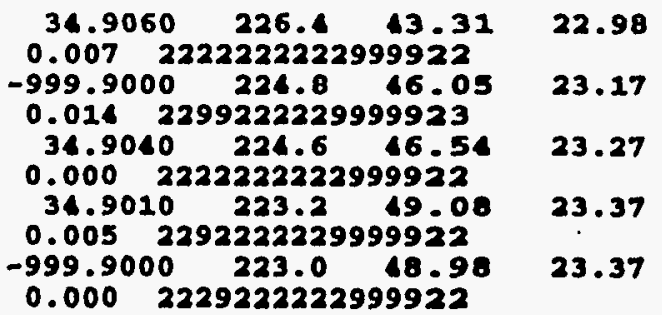


APPENDIX A

STATION INVENTORY 


\section{APPENDIX A STATION INVENTORY}

This appendix lists station inventory information for the 111 sites occupied during R/V Meteor Cruise $15 / 3$ in the South Atlantic Ocean. The meanings of the column headings in Table A-1 are as follows.

EXPOCODE is the expocode of the cruise;

STNNBR is the station number;

SECT is the WOCE section number;

CASTNO is the cast number;

DATE is the sampling date (month/day/year);

TIME $\quad$ is the sampling time (GMT);

LATDCM is the latitude of the station (in decimal degrees). Stations in the Southern Hemisphere have negative latitudes;

LONDCM is the longitude of the station (in decimal degrees). Stations in the Westem Hemisphere have negative longitudes;

DEPTH is the sounding bottom depth of each station (in meters). 
Table A.1 Station inventory information for the 111 sites occupied during R/V Meteor Cruise 15/3.

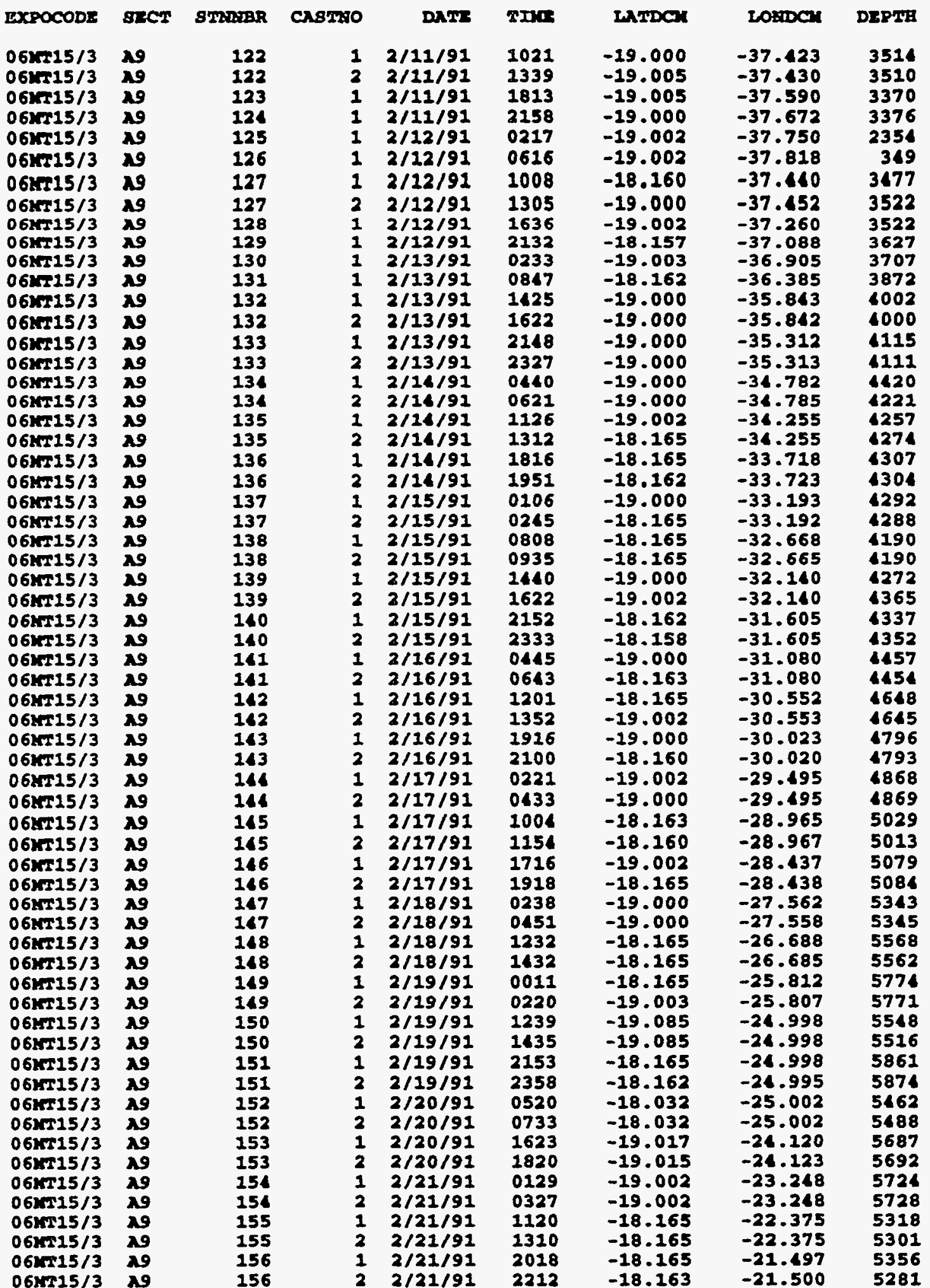


Table A.1 (continued)

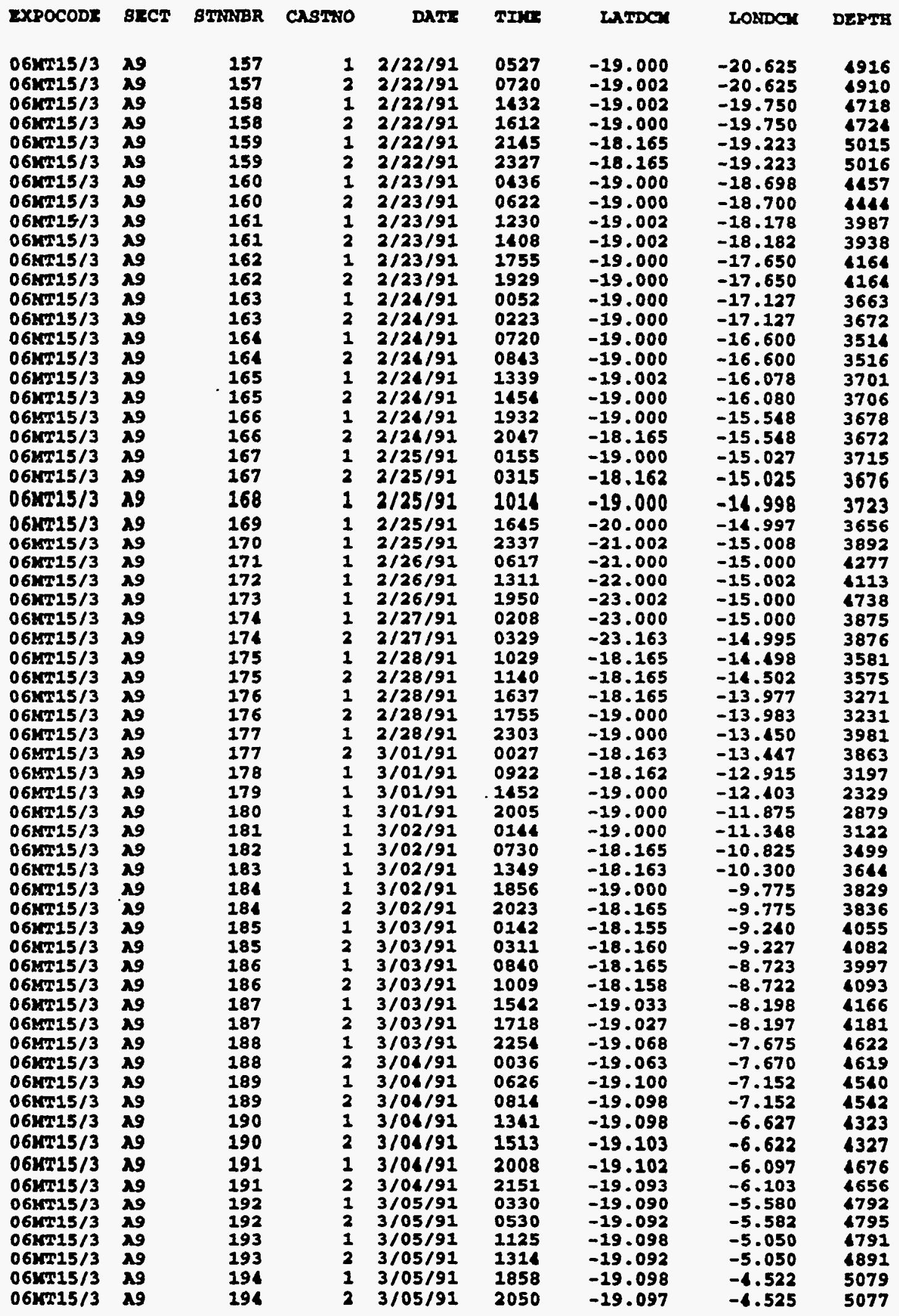


Table A.1 (continued)

\begin{tabular}{|c|c|c|c|c|c|c|c|c|}
\hline IXXPOCODE & BsCT & STMRABR & CAsmato & DNT: & TIn & IXITDC: & IOSTDCX & DEPTH \\
\hline $\begin{array}{l}06 \operatorname{Mr} 15 / 3 \\
06 \operatorname{Mr} 15 / 3 \\
06 \operatorname{Mr} 15 / 3 \\
06 \operatorname{Mr} 15 / 3 \\
06 \operatorname{Mr} 15 / 3\end{array}$ & 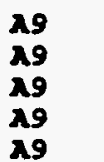 & $\begin{array}{l}230 \\
231 \\
231 \\
232 \\
232\end{array}$ & $\begin{array}{l}2 \\
1 \\
2 \\
1 \\
2\end{array}$ & $\begin{array}{l}3 / 18 / 91 \\
3 / 18 / 91 \\
3 / 18 / 91 \\
3 / 18 / 91 \\
3 / 18 / 91\end{array}$ & $\begin{array}{l}0532 \\
1056 \\
1218 \\
1931 \\
2051\end{array}$ & $\begin{array}{l}-18.072 \\
-17.028 \\
-17.028 \\
-17.025 \\
-17.025\end{array}$ & $\begin{array}{l}10.007 \\
10.483 \\
10.483 \\
10.807 \\
10.805\end{array}$ & $\begin{array}{l}\$ 124 \\
3590 \\
3598 \\
3047 \\
3045\end{array}$ \\
\hline
\end{tabular}

